\title{
Endorsement of Global Product Brands by Global Corporate Brands - A Consumer Perspective Across Nations
}

\author{
Bernhard Swoboda ${ }^{1} \cdot$ Carolina Sinning $^{1}$
}

Received: 15 January 2021 / Revised: 31 May 2021 / Accepted: 26 June 2021 /

Published online: 18 August 2021

(C) The Author(s) 2021

\begin{abstract}
Many multinational corporations use their corporate brand to endorse their products but thereby attract international consumers differently. Therefore, it is important to analyze whether corporations profit from endorsed branding strategies across nations or whether they must rely on country-specific factors. The authors propose a theory-based framework and apply multilevel mediation structural equation modeling with cross-level interactions to analyze the typical direct and indirect effects of global corporate brand image and global product brand image on product purchase intention across nations. The authors rely on hierarchical data from 7660 consumer evaluations of a multinational corporation's global corporate and product brands in 35 countries. Importantly, the results provide insights into country-specific moderators, i.e., the degree of country development and national culture, and the respective country portfolio. They further contribute to the application of theory and show a positive indirect effect of global corporate brand image on product purchase intention via global product brand image across nations. Additionally, a positive, although weaker, direct effect of global corporate brand image on product purchase intention is found. However, the degree of country development and national culture moderate both effects differently. This study provides new theoretical implications and shows that a country portfolio offers concrete hints for managers.
\end{abstract}

Keywords Endorsed branding strategy - Global corporate and product brands . Cross-national research $\cdot$ Multilevel structural equation modeling $\cdot$ Sub-branding

Bernhard Swoboda

b.swoboda@uni-trier.de

Carolina Sinning

c.sinning@uni-trier.de

1 Chair for Marketing and Retailing at the University of Trier, Universitaetsring 15, 54296 Trier, Germany 


\section{Introduction}

Multinational corporations (MNCs) applying an endorsed branding strategy, i.e., the use of a distinct global corporate brand as a visual endorsement of global product brands, can experience demand benefits (Hsu et al., 2016). Therefore, MNCs place their corporate brand name/logo on products with the product brand still more prominently positioned (Keller, 2012, p. 302). Based on the endorser, consumers can identify a product with an $\mathrm{MNC}$, which attracts them in making product purchase decisions (Khojastehpour \& Johns, 2015). Although many MNCs, such as Danone, L'Oréal, Tyson, or Nestlé, change product or corporate dominant strategies, i.e., branded house or house of brands, towards an endorsed branding (Brexendorf \& Keller, 2017, versus sub-branding), their strategies' effects are not equal across nations. For example, Kellogg's has long used its global corporate brand to support its global product brands (e.g., Smacks, Frosties) to profit from positive image transfers in terms of consumer behavior. However, since 2019, Kellogg's has adjusted its strategy for Europe by accounting for cultural differences (Kellogg's, 2019). Additionally, other MNCs, such as Unilever, have had to adjust their branding strategy, for example, in emerging countries (after losing market share in China, Indonesia, and India, Gupta \& Wright, 2019). Hence, these MNCs need to consider endorsed branding across nations. Therefore, this study examines the direct effect of global corporate brand image, i.e., the endorser itself, and the indirect effect through global product brand image, i.e., the endorsed product brand, on product purchase intention across nations. This initial analysis provides new insights across nations and may validate the only nationally known effects (e.g., Samiee, 2019). We study the degree of country development and national culture as important national context factors.

Scholars recognize the importance of image transfers (see Table 1). Studies on horizontal image transfers analyze the links between product evaluations (e.g., in developed or emerging countries, Bian \& Moutinho, 2011 or Essoussi \& Merunka, 2007, or comparing countries, Davvetas \& Diamantopoulos, 2018) or horizontal brand extensions (new products under a brand, e.g., Ahn et al., 2018; Boisvert \& Ashill, 2018; Chang et al., 2011). Studies on vertical image transfers often consider celebrity endorsement or vertical brand extensions (e.g., Allman et al., 2016, 2019; Chen \& Wyer Jr, 2020; Derdenger, 2018) but seldom corporate and product brands. When the latter are included, the focus is only on corporateproduct evaluation-links but not effects (e.g., Biehal \& Sheinin, 2007; Abosag \& Farah, 2014; in two countries, Heinberg et al., 2018; Souiden et al., 2006). Few scholars study the effects of corporate and product brands on purchase intentions or intentional loyalty (with differences in emerging versus developed countries, Fatma et al., 2016; Wang et al., 2008, versus Cretu \& Brodie, 2007; Suh \& Youjae, 2006). Jakubanecs and Supphellen (2012) is the only study analyzing corporate-product brand-links in more countries (six); however, it does not consider their effects. Consequently, studies on the effects of important global endorsed branding on consumer behavior across nations are missing, and studies have not sufficiently considered contradictory effects in emerging versus developed 


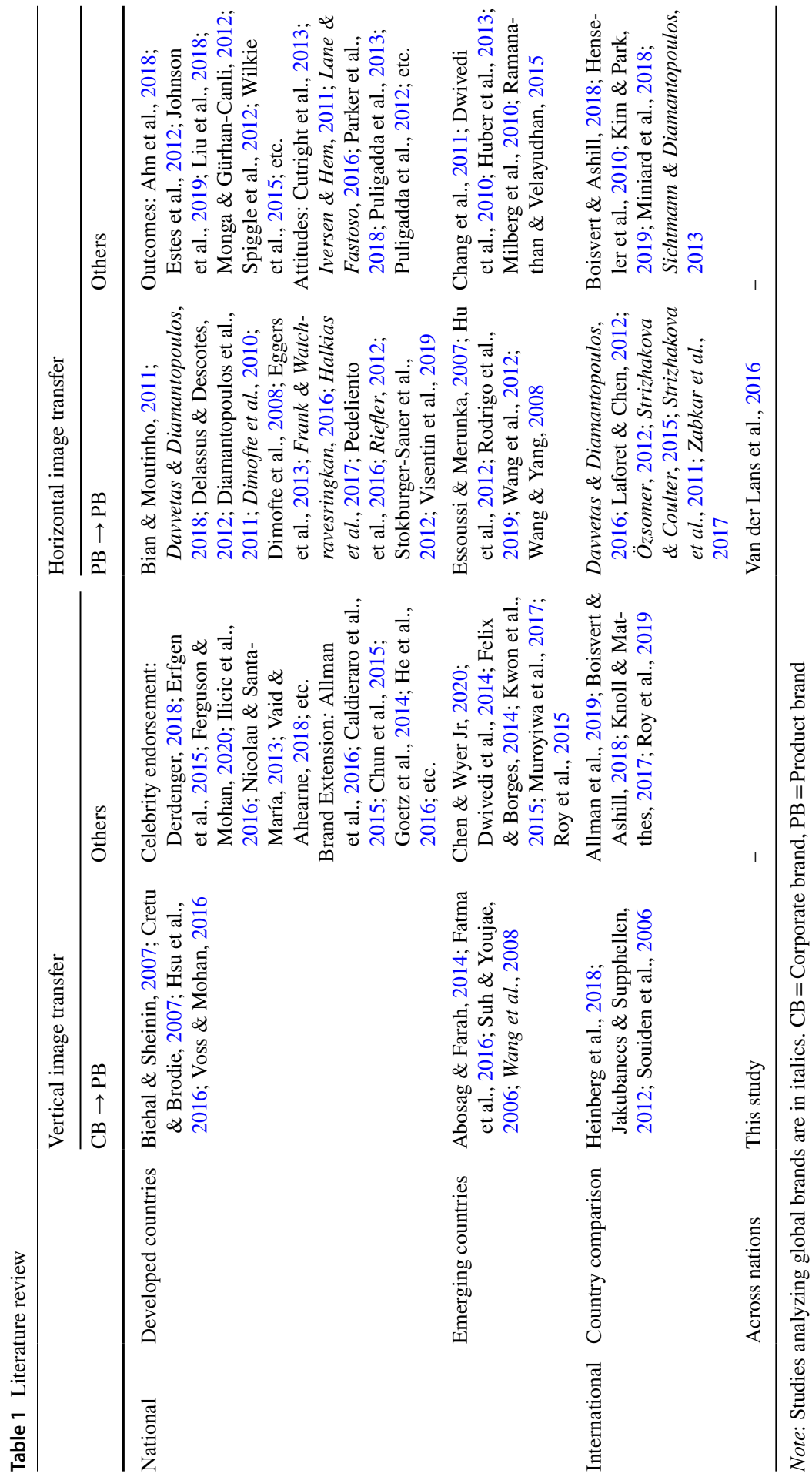


countries (e.g., for horizontal image transfers, Özsomer, 2012; Strizhakova \& Coulter, 2015). Moreover, vertical image transfers seem to vary due to national culture (especially for collectivism, Jakubanecs \& Supphellen, 2012). However, the general brand research provides contradictory assumptions on culture: Van der Lans et al. (2016) show a moderation of culture for the effects of brands on purchase intention; Steenkamp (2019a) questions the link between culture and brand attitude. Thus, important national contextual factors must be studied for global corporations' endorsement of global product brands (consumer factors such as ethnocentrism dominate, Roy et al., 2019).

In summary, scholars have not considered the role of global corporate brands in supporting global product brands and their effects on purchase intentions across nations. There have been calls for such studies to generalize and validate nationally known effects globally (Brexendorf \& Keller, 2017; Samiee, 2019). More importantly, insights on important boundary conditions, i.e., degree of country development and national culture, for global endorsed branding are missing (Heinberg et al., 2018). Respective knowledge is important for those managers responsible for endorsed branding at headquarters as they learn whether this strategy is beneficial across nations from the target group perspective. Predominant boundary conditions in branding research allow country-specific portfolios to be generated as a basis for decisions on where to rely on or strengthen endorser strategy effects and where not.

We aim to address these research gaps by analyzing the following research questions. First, how can MNCs benefit from an image transfer of global corporate to product brands in terms of product purchase intention across nations? Second, do the degrees of country development and national culture moderate the indirect and direct effects of global corporate brand image, and if so, how strong? We thereby offer two important contributions to theory and practice.

First, analyzing the relationship between corporate and product brands across nations provides novel insights into the global application of the endorsed branding strategy. Studies on vertical image transfers investigate endorsed branding holistically (comparing branding strategies, e.g., Hsu et al., 2016, or corporate-productlinks only, e.g., Jakubanecs \& Supphellen, 2012). Our focus on global brand effects across nations extends the very few international studies. We clarify how global endorsers and endorsed brands contribute to consumers' product brand purchase intentions. Moreover, whereas studies on image transfers refer to categorization, associative network or signaling theory, we aim to contribute to the application of schema theory as a promising new rationale for endorsed branding and moderation effects across nations. Corporate and product brand images represent consumers' brand knowledge stored in respective brand schemata (Halkias, 2015). In product purchase situations, consumers activate dominant product brand schemata and can also activate the corporate brand schema (transmitting it to product brands, MeyersLevy \& Tybout, 1989).

Second, we contribute to the research by examining the degree of country development and national culture as moderators (following calls, Wang et al., 2017). Schema theory suggests that such environmental and cultural differences shape consumers' brand schema structure and activation in memory by determining their brand schematicity (e.g., Davvetas \& Diamantopoulos, 2016; Halkias, 2015; 
Puligadda et al., 2012). By referring to this theory, we add to studies analyzing vertical image transfers in emerging or developed countries (e.g., Abosag \& Farah, 2014; Biehal \& Sheinin, 2007). Certain emerging markets become important for MNCs as they report strong economic growth (Heinberg et al., 2017). Revealing differences in emerging versus developed markets also enables MNCs to exploit the growth potential of an endorser strategy (He \& Wang, 2017). Analyzing national culture contributes to understanding inconsistent results and accounts for how culture affects endorsed branding. Corresponding to the most often viewed Hofstede's cultural dimensions, collectivism, in the brand research (e.g., Gupta et al., 2018; Jakubanecs \& Supphellen, 2012), the embeddedness dimension of Schwartz (1994) is referenced here. Compared to Hofstede, Schwartz's model is more theoretically profound, considers guidance of behavior, and reports high empirically explained variances (e.g., De Mooij, 2017; Swoboda \& Batton, 2019). Moreover, embeddedness is theoretically and empirically the most important cultural dimension in global brand perceptions (e.g., Swoboda \& Sinning, 2020). Finally, we use multilevel mediation structural equation modeling (MSEM) with cross-level interactions and conditional effects (Hox et al., 2018, pp. 4-5; Spiller et al., 2013) to study the leverage effects of the moderators in a country portfolio (including conclusions beyond the countries analyzed).

The remainder of this study proceeds as follows. Drawing from theory, we derive and test hypotheses based on 7660 consumer evaluations of global brands across 35 nations. After presenting the results, we provide implications and directions for further research.

\section{Conceptual Framework and Hypothesis}

To address our research aims, we build on schema theory and empirical studies.

Scholars differentiate four branding strategies: house of brands reflects a purely product strategy, and branded house reflects a purely corporate strategy (e.g., Gillette of P\&G and Nike); sub-branding and endorsed branding are categorized within those extremes. Sub-branding applies equally to corporate and product brands, e.g., Sony PlayStation, VW Golf (as in national studies, e.g., He et al., 2016; Hsu et al., 2016). In contrast, endorsed branding links corporate and product brands to a lesser extent, e.g., the corporate brand name appears on the product package, not as part of the product brand name (Brexendorf \& Keller, 2017).[1] As mentioned, it is particularly interesting globally, as leading MNCs use global corporate and global product brands to attract consumers (Davvetas \& Diamantopoulos, 2016; Swoboda \& Sinning, 2020). However, for endorsed branding, the indirect and direct effects of MNCs' global corporate brand image via global product brand image on consumers' product brand purchase intention must be studied initially (i.e., the likelihood that consumers will buy a product brand, Van der Lans et al., 2016; see Fig. 1). Generally, brand image is defined as the brand perceptions reflected by the brand associations in consumers' minds (Keller, 1993). Specifically, corporate brand image represents consumers' mental picture of an MNC (Gray \& Balmer, 1998; Souiden et al., 


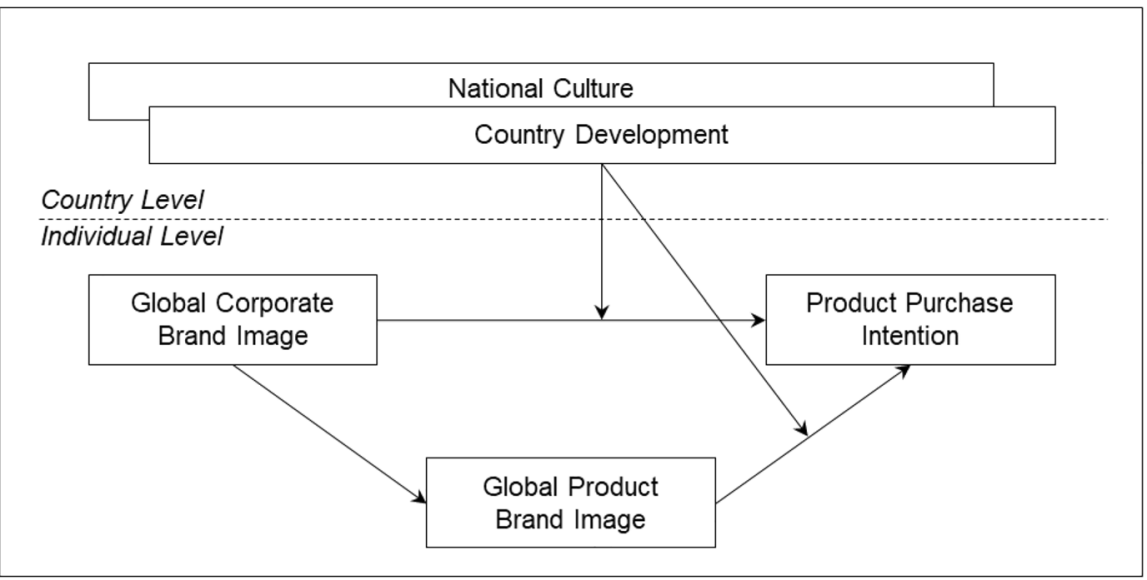

Fig. 1 Conceptual framework

2020), and product brand image represents consumers' mental picture of a global product brand (Park et al., 1986; Plumeyer et al., 2019).

We study the roles of continuous national moderators: degree of country development (i.e., countries' economic growth, social, and human conditions, Çilingirtürk \& Koçak, 2018), and embeddedness (i.e., social structures between groups and individuals within a society characterizing individuals for whom conformance with group norms or belonging to the community are important, Schwartz, 1994).

\subsection{Theory}

Schema theory addresses memory-stored cognitive structures that organize consumers' prior knowledge about objects (Fiske \& Taylor, 1991, p. 98). Those schemata are structured hierarchically such that superordinated schemata subsume various subschemata. Superordinated schemata are characterized by more generic associations and interact with subordinated schemata incorporating more specific attributes (Crocker, 1984). Additions to information incorporated into a subschema lead to changes in the attributes associated with the respective subschema and the corresponding superordinated schema. Thus, super- and subordinated schemata guide the reception and retrieval of information and are used for decision-making (Sujan \& Bettman, 1989). Consumers' environmental and cultural socialization determines their schema structure and schematicity (e.g., Davvetas \& Diamantopoulos, 2016; Shaw, 1990). For example, brand-schematic (versus aschematic) consumers develop and activate super- and subschemata more easily (Puligadda et al., 2012).

In our context, global corporate and product brand schemata organize prior brand knowledge in consumers' minds. Brand image is a common construct for illustrating consumers' brand knowledge (Halkias, 2015). Hence, global corporate brand image reflects consumers' corporate brand associations stored in the global corporate brand schema, while global product brand image reflects their product brand associations in the product brand schema (Hoyer et al., 2012, p. 108). The product 
brand represents a subschema of the superordinated corporate brand schema. For example, new product brand information received in a product purchase situation is primarily incorporated into the respective product brand subschema but also into the corporate brand schema (Meyers-Levy \& Tybout, 1989). In such situations, consumers activate the respective product brand subschema and transfer the superordinated, more generic, corporate brand image to the more specific product brand image. This procedure affects product purchase intention. Moreover, the retrieved global corporate brand schema may affect global product purchase behavior (Biehal \& Sheinin, 2007).

As indicated, the cognitive processes of consumers' brand schema development and activation differ in country-specific contexts (e.g., Crocker, 1984; Halkias, 2015). Generally, the degree of country development determines consumers' brand schematicity such that consumers in less developed countries tend to be more brandaschematic due to weaker corporate and product brand knowledge (Heinberg et al., 2017; Sheth, 2011). For brand-aschematic consumers, the image transfer from the corporate to the product brand is known to be weaker when determining their product purchase intention (Puligadda et al., 2012). Schemata also depend on one's national cultural socialization (e.g., Crocker, 1984). The cultural dimension of valuing the group is said to particularly affect consumers' schema activation and structure (versus other cultural dimensions that more determine activation, Shaw, 1990). As super- and subordinated schema structures are analyzed, we focus on embeddedness, which induces schema structures to be more homogeneous (Schwartz, 1994). A homogeneous schema structure encourages consumers' brand schematicity and enables consumers to more easily activate and link the global corporate brand to the global product brand in product purchase situations.

Next, the study's hypotheses are derived referring to theoretical as well as empirical insights. First, arguments for the hypotheses on the indirect and direct effects of global corporate brand image as well as their relative strengths are provided. Second, for each moderator, the rationales of their roles in the indirect and direct effects are developed.

\subsection{Hypothesis Development}

Theoretically, superordinated global corporate brand schemata indirectly and directly affect product purchase intention. In product purchase situations, the activation of global product brand schemata is highly relevant (Biehal \& Sheinin, 2007; Davvetas \& Diamantopoulos, 2016). Thus, consumers activate product-related schemata for decision-making purposes (Halkias, 2015). When an MNC applies endorsed branding, indicated by the indirect effect, consumers can identify the product with the MNCs' global corporate brand (Brexendorf \& Keller, 2017). Hence, the use of endorsed branding enables consumers to link superordinated corporate brand schemata to subordinated product brand schemata. Through this link, the overall corporate brand image is transferred and adds value to product brands (Souiden et al., 2006). This image transfer is especially strong for global brands due to their high recall and availability (Xie et al., 2015). Consumers use global corporate brand 
information to supplement global product brand images (Heinberg et al., 2018) and, consequently, determine consumers' product purchase intention. We argue that this mechanism holds across nations, even if the literature has indicated country differences. Empirically, national studies underscore a transmission from corporate brand associations to product brand attitudes to evaluate product brands (e.g., in loyalty and repurchase intention models, Fatma et al., 2016; Wang et al., 2008). Internationally, only Jakubanecs and Supphellen (2012) suggest that corporate endorsement positively affects product brand attitudes when comparing country groups.

Moreover, regarding the direct effect, we assume that global corporate brand schemata are activated directly to determine consumers' behavior towards MNCs' global product brands. Corporate image is important information consumers use to evaluate product brands (Souiden et al., 2006). Furthermore, global corporate brands are known to deliver functional and psychological benefits, which are translated into beneficial consumer behavior across nations (Swoboda \& Sinning, 2020). Some authors in our literature review indicated a positive direct effect of corporate image on product brand equity (e.g., in two countries, Heinberg et al., 2018).

Finally, because of the predominant relevance of global product brand image in product purchase situations (Biehal \& Sheinin, 2007), the indirect (versus direct) effect of corporate brand image on product purchase intention is assumed to be stronger. Global corporate brand schemata also affect global product brand schemata through consumers' retrieval of global product and corporate images. Hence, the endorsed branding strategy is assumed to more strongly affect consumers' product purchase intention than the endorser itself. In summary, endorsement offers distinct value to the product brand and consumers' decision-making within product purchase situations. We propose the following:

Hypothesis 1: Across nations, global corporate brand image has (a) a positive indirect effect on consumers' product purchase intention via global product brand image and (b) a positive direct effect on consumers' product purchase intention, wherein $(c)$ the indirect effect is stronger than the direct effect.

The effects of the endorsed branding, i.e., the indirect effect, and the endorser, i.e., the direct effect, differ depending on the degree of country development, which determines consumers' brand knowledge and brand schematicity (Puligadda et al., 2012; Sheth, 2011). Consumers in developed countries are highly familiar with global brands, have well-structured brand schemata and are known to be more brand-schematic (Bahadir et al., 2015; Puligadda et al., 2012). In contrast, consumers in less developed countries tend to have lower brand knowledge due to their relatively short brand history, unbranded product variety or heterogeneous demand (e.g., Heinberg et al., 2017; Sheth, 2011). The reduced brand experience makes them more brand-aschematic (Puligadda et al., 2012).

Developed countries are homes of strong brands where specific product (versus corporate) brand attributes are particularly more important in product purchase situations than they are in emerging countries (e.g., Davvetas \& Diamantopoulos, 2016; Hsieh et al., 2004). Thus, in product purchase situations, consumers in developed countries rely on global product brand schemata to determine their product purchase intention. Additionally, for such brand-schematic consumers, it is easier to activate and link global corporate and product brand schemata (Halkias, 2015). The 
endorsed branding strategy makes it easier for consumers to transfer the superordinated corporate brand image to the subordinated product brand image for purchase decisions about global product brands. In contrast, more brand-aschematic consumers have a weaker transfer of the corporate brand image to the product brand image, more strongly relying on the superordinated global corporate brand image in product purchase situations. Thus, we assume an increasing degree of country development to enhance indirect, endorsed branding, effects.

However, in emerging countries, where unbranded competition is high, branded products may become less attractive as the importance of global corporate brands increases (e.g., Bahadir et al., 2015). Moreover, even when consumers are more brand-aschematic, they may still activate superordinated global corporate brand schemata directly when not being questioned in common situations to link them to respective subordinated product brand schemata (Puligadda et al., 2012). They may not be brand experts but recognize global corporate brands due to their high standardization and availability (Heinberg et al., 2017; Xie et al., 2015). Generally, global (versus local) brands are preferred as they deliver benefits such as security and entrance to global citizenship in less stable political and economic environments (Özsomer, 2012; Strizhakova et al., 2011). Empirical studies confirm that corporate brand image is particularly valued for guidance in decision-making in emerging countries (e.g., India or China, Heinberg et al., 2018). We carefully assume that consumers in emerging (versus developed) countries more strongly retrieve the global corporate brand schema, the endorser itself, directly to determine their product purchase intention.

In summary, consumers in more developed countries rely more strongly on product-related brand information and can easily transfer the global corporate brand image to the global product brand image, whereas consumers in emerging countries place more emphasis on global corporate brands. Hence, an increasing degree of country development enhances the indirect but may diminish the direct effect on product purchase intention. We hypothesize as follows:

Hypothesis 2: Across nations, the degree of country development positively moderates (a) the indirect effect of global corporate brand image on consumers' product purchase intention via global product brand image, whereas it negatively moderates (b) the direct effect of global corporate brand image on consumers' product purchase intention.

National cultural value dimension embeddedness is assumed to affect the indirect and direct effects of global corporate brand image on product purchase intention. Embeddedness determines consumers' brand schematicity and their schema structure (Shaw, 1990). Individuals in highly embedded societies value tradition, group norms and conformance with the group (Camacho et al., 2014; Schwartz, 1994). As schemata are tied to values and the ideology of the culture and are usually shared within a given population, this behavior and thinking based on preferences of the group make respective cognitive schemata more homogeneous (e.g., Crocker, 1984; Davvetas \& Diamantopoulos, 2016; Shaw, 1990). Individuals with such homogeneous schema structures can be characterized as more brand-schematic and more sensitive to global corporate and product brand information (e.g., Halkias, 2015; Puligadda et al., 2012). 
We assume a strengthened indirect effect of global corporate brand image on product purchase intention with an increase in embeddedness. Theoretically, based on the high brand-schematicity in societies, an activation and link of superordinated corporate and subordinated product brand schemata due to the endorsed branding strategy should be easier (Shaw, 1990). Individuals in such societies strive to belong to and to be part of the community (e.g., De Mooij, 2017; Schwartz, 1994). As brand-schematic consumers, they further value wealth and status (Puligadda et al., 2012) and, in turn, global corporate and product brands, as they are proven to make consumers feel part of a community and to provide status (e.g., Strizhakova \& Coulter, 2015). Thus, an endorsed brand appears to align with embeddedness, which makes it attractive in such countries. Such alignment and the ease of activating and linking respective brand schemata support beneficial consumer behavior in societies with an increasing degree of embeddedness (Sujan \& Bettman, 1989). Empirical studies support this reasoning. National studies have found stronger effects of product brand attributes on behavior for consumers who emphasize group (versus individual) interests (Thompson et al., 2014). For image transfers, country comparisons have indicated that corporate endorsement/image more positively affects product brand evaluation in societies that strongly value the group (e.g., Jakubanecs \& Supphellen, 2012; Souiden et al., 2006).

We also assume a strengthened direct effect of global corporate brand image on product purchase intention with an increase in the embeddedness of societies. Theoretically, brand-aschematic consumers may also directly activate global corporate brand schemata in product purchase situations when not linking it to product brand schemata (Puligadda et al., 2012). However, individuals in embedded societies tend to more strongly prefer global corporate brands (Gupta et al., 2018). In addition to relying on traditions, they are open to the new and foreign brands (De Mooij, 2017). This may enable them to ensure family security and build social relationships (Camacho et al., 2014). Global corporate brands are known to deliver high functional benefits to improve group interest and psychological benefits in building social relationships (Swoboda \& Sinning, 2020). Such cultural values appear to be consistent with the communication of the global corporate endorser (e.g., Swoboda \& Batton, 2019). Due to this conformity of cultural values with the corporate endorser, the global corporate brand schema may gain importance in product purchase situations in which consumers retrieve it directly. Empirically, studies have indicated that the effect of corporate brand signals and associations on consumer behavior is stronger in more (versus less) socializing countries (e.g., Erdem et al., 2006; Swoboda et al., 2016).

In summary, we assume an increasing degree of embeddedness to enhance the indirect and direct effects of global corporate brand image through global product brand image on product purchase intention. We propose the following:

Hypothesis 3: Across nations, embeddedness positively moderates (a) the indirect effect of global corporate brand image on consumers' product purchase intention via global product brand image and $(b)$ the direct effect of global corporate brand image on consumers' product purchase intention. 


\section{Empirical Study}

\subsection{Sample}

The data derive from cooperation with a German MNC with subsidiaries in 150 countries offering nonprescription drugs, crop products, skin/beauty care, consumer goods, and services. The MNC uses a standardized, centrally managed global corporate brand. In 2018, a specific study was conducted in 35 countries selected due to their importance for the MNC (360 respondents per country). We conceptualized the study and preselected global product brands, i.e., those offered on at least three continents with the same brand name and a similar marketing strategy as the most important criteria of globality (Gürhan-Canli et al., 2018; Steenkamp, 2019b; controlling for further criteria, Samiee, 2019). In doing so, four product categories were selected: nonprescription drugs, consumer care, consumer goods for animals, and crop products. The ten or fewer leading product brands in each category were identified using data from the MNC. To ensure brand knowledge and familiarity, seven product brands with the highest market share in each category were chosen. For every product brand in every country, we intensively collected information (on respective websites, in calls with local product managers) to control the characteristics of globality (i.e., brand name, availability) and endorsement (i.e., product packages). For the survey, we ultimately chose consumer products that were clearly endorsed on the front of the product package, five per category. We and a marketing research agency conducted qualitative and quantitative pretests. First, the scales and the questionnaire design were pretested by two consumer focus groups. Second, the scales were quantitatively pretested in the home country and in seven of the most important foreign countries for the MNC based on a cross-national panel approach $(\mathrm{N}=130$ each, quota sample). The pretests yielded satisfactory results for face validity, possible hierarchy of effects, awareness of all 20 global product brands, and enhanced construct equivalence after minor item adjustments as well as reliability and validity of the measurements.

The agency collected the data for the main study (average participation rate of $66 \%$ ). Text-appealing strategies were used to highlight the public benefit of participating, and bonus points were offered (Pedersen \& Nielsen, 2016). The quality of the panel was ensured by accounting for individualized survey links, instructional manipulation checks, or response times (Abbey \& Meloy, 2017). Quota sampling related to gender and age was applied based on information from national registration offices. Additionally, screening criteria were used to further increase the comparability of responses across nations. The sample was limited to the urban population between 18 and 65 years old with higher educational or professional levels (at least a higher school education, Özsomer, 2012). Initially, the respondents had to indicate their (un)prompted awareness of the MNC (based on a five-point Likert-type scale, $1=\mathrm{I}$ do not know the MNC to $5=\mathrm{I}$ know the MNC very well; Keller, 1993). Only respondents with at least general knowledge (=2) of the MNC were included in the survey, leading to 11,335 evaluations. 
Regarding the product brands, (un)prompted awareness was also assessed, and only respondents with at least general knowledge $(=2)$ of two or more product brands were included in the survey (8,058 respondents). We randomly chose one of two product brands for evaluation (despite a product category): alternately more and less known. After eliminating Mahalanobis distance-based outliers, 7660 respondents remained (Table 2). The data were not normally distributed. Thus, a maximum likelihood estimator with robust standard errors and chi-square test statistics was used to test the hypotheses (Maydeu-Olivares, 2017).

\subsection{Measurement}

Individual-level variables were measured using five-point Likert-type scales (from $1=$ strongly disagree to $5=$ strongly agree; see Table 3 ). For corporate brand image, we relied on four items adapted from Keller (1993). Product brand image was measured with four items (Salinas \& Pérez, 2009). Three items were used to measure product purchase intention (Putrevu \& Lord, 1994; widely used in brand research, e.g., Davvetas \& Diamantopoulos, 2016). Parallel blind translation-back-translation, with translation reviews, was applied by a commercial translation agency. To maximize construct equivalence (e.g., Yang et al., 2019), minor item adjustments, i.e., cultural rephrasing, were made (Watkins, 2010).

The country-level variable degree of country development was measured by the Human Development Index (HDI, United Nations Development Programme, 2018). The HDI consists of three indices (life expectancy, education, and gross national income) and is the predominant measure of country development (e.g., Çilingirtürk $\&$ Koçak, 2018). The national cultural dimension embeddedness was based on the most recent data available from Schwartz (1994).[2] We relied on embeddedness due to model complexity and its predominant role in the global brand research (e.g., highest explanatory power among cultural value dimensions, Swoboda \& Batton, 2019; Swoboda \& Sinning, 2020).

On the individual level, we controlled for gender $(0=$ male, $1=$ female $)$, age, brand familiarity (measured by one item, "How familiar are you with [MNC] and its product brands?", Steenkamp et al., 2003), and the four product brand categories (categorical, e.g., Mandler, 2019). The controls may affect consumers' brand schematicity and, thus, how the schemata are activated for product purchase intention (Halkias, 2015; Puligadda et al., 2012). On the country level, the number of respondents in each country was controlled to prevent an unequal number from affecting the results (e.g., Hox et al., 2018, p. 215). Lettering, coloring, and language for the corporate and product brands on the product package were controlled (dummy variables: $0=$ standardized, $1=$ adapted). These are important controls that may affect brand perception and the development of schemata (Buechel \& Townsend, 2018; Carnevale et al., 2017; Kim et al., 2018).

As consumers are nested in countries, multilevel modeling requirements were tested. Intra-class correlation, estimated within a null model without any predictor variables, indicated that $11.0 \%$ of the variance in product purchase intention is attributable to country differences. Thus, multilevel modeling was needed (Hox 
Table 2 Sample distribution

\begin{tabular}{|c|c|c|c|c|c|c|c|c|}
\hline & \multirow[t]{2}{*}{$\mathrm{N}$} & \multicolumn{2}{|c|}{ Gender (\%) } & \multicolumn{5}{|c|}{ Age groups (years, \%) } \\
\hline & & Male & Female & $18-25$ & $26-35$ & $36-45$ & $46-55$ & $56-65$ \\
\hline Argentina & 137 & $65.7 \%$ & $34.3 \%$ & $19.7 \%$ & $25.5 \%$ & $23.4 \%$ & $15.3 \%$ & $16.1 \%$ \\
\hline Australia & 152 & $61.8 \%$ & $38.2 \%$ & $10.5 \%$ & $31.6 \%$ & $20.4 \%$ & $15.8 \%$ & $21.7 \%$ \\
\hline Belgium & 373 & $65.4 \%$ & $34.6 \%$ & $17.7 \%$ & $21.2 \%$ & $23.1 \%$ & $21.2 \%$ & $16.9 \%$ \\
\hline Brazil & 150 & $62.0 \%$ & $38.0 \%$ & $50.0 \%$ & $26.7 \%$ & $14.7 \%$ & $8.7 \%$ & $0.0 \%$ \\
\hline Canada & 112 & $57.1 \%$ & $42.9 \%$ & $17.0 \%$ & $29.5 \%$ & $18.8 \%$ & $17.9 \%$ & $17.0 \%$ \\
\hline Chile & 156 & $61.5 \%$ & $38.5 \%$ & $19.2 \%$ & $33.3 \%$ & $38.5 \%$ & $9.0 \%$ & $0.0 \%$ \\
\hline China & 167 & $53.9 \%$ & $46.1 \%$ & $32.3 \%$ & $22.8 \%$ & $19.8 \%$ & $25.1 \%$ & $0.0 \%$ \\
\hline Croatia & 202 & $68.3 \%$ & $31.7 \%$ & $7.9 \%$ & $26.7 \%$ & $48.0 \%$ & $17.3 \%$ & $0.0 \%$ \\
\hline Czech Republic & 193 & $71.0 \%$ & $29.0 \%$ & $8.8 \%$ & $16.6 \%$ & $22.3 \%$ & $24.4 \%$ & $28.0 \%$ \\
\hline Egypt & 246 & $74.8 \%$ & $25.2 \%$ & $29.7 \%$ & $29.3 \%$ & $29.7 \%$ & $11.4 \%$ & $0.0 \%$ \\
\hline Finland & 206 & $63.6 \%$ & $36.4 \%$ & $21.8 \%$ & $18.0 \%$ & $20.9 \%$ & $18.4 \%$ & $20.9 \%$ \\
\hline France & 256 & $53.9 \%$ & $46.1 \%$ & $21.9 \%$ & $22.7 \%$ & $16.8 \%$ & $11.7 \%$ & $27.0 \%$ \\
\hline Germany & 189 & $54.5 \%$ & $45.5 \%$ & $27.5 \%$ & $19.6 \%$ & $21.7 \%$ & $20.6 \%$ & $10.6 \%$ \\
\hline Hungary & 202 & $55.4 \%$ & $44.6 \%$ & $11.4 \%$ & $20.3 \%$ & $16.3 \%$ & $19.8 \%$ & $32.2 \%$ \\
\hline India & 169 & $52.7 \%$ & $47.3 \%$ & $18.9 \%$ & $19.5 \%$ & $27.8 \%$ & $33.7 \%$ & $0.0 \%$ \\
\hline Ireland & 182 & $57.1 \%$ & $42.9 \%$ & $15.9 \%$ & $26.9 \%$ & $22.0 \%$ & $22.0 \%$ & $13.2 \%$ \\
\hline Italy & 506 & $55.1 \%$ & $44.9 \%$ & $12.8 \%$ & $20.8 \%$ & $20.8 \%$ & $23.5 \%$ & $22.1 \%$ \\
\hline Japan & 254 & $49.2 \%$ & $50.8 \%$ & $10.6 \%$ & $12.2 \%$ & $16.1 \%$ & $27.6 \%$ & $33.5 \%$ \\
\hline Malaysia & 271 & $53.9 \%$ & $46.1 \%$ & $15.9 \%$ & $26.9 \%$ & $24.0 \%$ & $23.6 \%$ & $9.6 \%$ \\
\hline Mexico & 139 & $60.4 \%$ & $39.6 \%$ & $43.9 \%$ & $20.1 \%$ & $20.9 \%$ & $15.1 \%$ & $0.0 \%$ \\
\hline Netherlands & 234 & $56.8 \%$ & $43.2 \%$ & $16.7 \%$ & $20.1 \%$ & $25.2 \%$ & $17.9 \%$ & $20.1 \%$ \\
\hline New Zealand & 117 & $65.0 \%$ & $35.0 \%$ & $17.1 \%$ & $17.9 \%$ & $26.5 \%$ & $20.5 \%$ & $17.9 \%$ \\
\hline Norway & 237 & $56.5 \%$ & $43.5 \%$ & $9.7 \%$ & $15.6 \%$ & $21.1 \%$ & $25.7 \%$ & $27.8 \%$ \\
\hline Poland & 259 & $59.5 \%$ & $40.5 \%$ & $16.2 \%$ & $20.5 \%$ & $18.5 \%$ & $24.7 \%$ & $20.1 \%$ \\
\hline Portugal & 159 & $63.5 \%$ & $36.5 \%$ & $7.5 \%$ & $27.0 \%$ & $50.9 \%$ & $14.5 \%$ & $0.0 \%$ \\
\hline Russia & 162 & $73.5 \%$ & $26.5 \%$ & $22.2 \%$ & $22.2 \%$ & $29.0 \%$ & $26.5 \%$ & $0.0 \%$ \\
\hline Saudi Arabia & 297 & $73.4 \%$ & $26.6 \%$ & $25.6 \%$ & $27.3 \%$ & $34.0 \%$ & $13.1 \%$ & $0.0 \%$ \\
\hline Singapore & 202 & $55.0 \%$ & $45.0 \%$ & $14.9 \%$ & $26.2 \%$ & $26.2 \%$ & $21.3 \%$ & $11.4 \%$ \\
\hline Slovakia & 272 & $62.5 \%$ & $37.5 \%$ & $11.0 \%$ & $23.2 \%$ & $22.4 \%$ & $20.2 \%$ & $23.2 \%$ \\
\hline Spain & 245 & $56.7 \%$ & $43.3 \%$ & $19.2 \%$ & $23.3 \%$ & $26.5 \%$ & $16.3 \%$ & $14.7 \%$ \\
\hline Turkey & 476 & $47.9 \%$ & $52.1 \%$ & $14.7 \%$ & $32.8 \%$ & $29.8 \%$ & $22.7 \%$ & $0.0 \%$ \\
\hline United Arab Emirates & 365 & $66.0 \%$ & $34.0 \%$ & $20.3 \%$ & $40.9 \%$ & $32.1 \%$ & $6.6 \%$ & $0.0 \%$ \\
\hline UK & 107 & $58.9 \%$ & $41.1 \%$ & $20.6 \%$ & $26.2 \%$ & $28.0 \%$ & $14.0 \%$ & $11.2 \%$ \\
\hline USA & 145 & $49.7 \%$ & $50.3 \%$ & $12.4 \%$ & $22.8 \%$ & $29.7 \%$ & $18.6 \%$ & $16.6 \%$ \\
\hline Venezuela & 121 & $61.2 \%$ & $38.8 \%$ & $16.5 \%$ & $37.2 \%$ & $38.0 \%$ & $8.3 \%$ & $0.0 \%$ \\
\hline Total & 7660 & $59.7 \%$ & $40.3 \%$ & $18.1 \%$ & $24.5 \%$ & $25.6 \%$ & $19.0 \%$ & $12.8 \%$ \\
\hline
\end{tabular}

et al., 2018, pp. 4-13). Reliability and validity tests across nations and in each country yielded satisfactory results (see Table 3 and Web Appendix F; Hair et al., 2018, p. 93). 


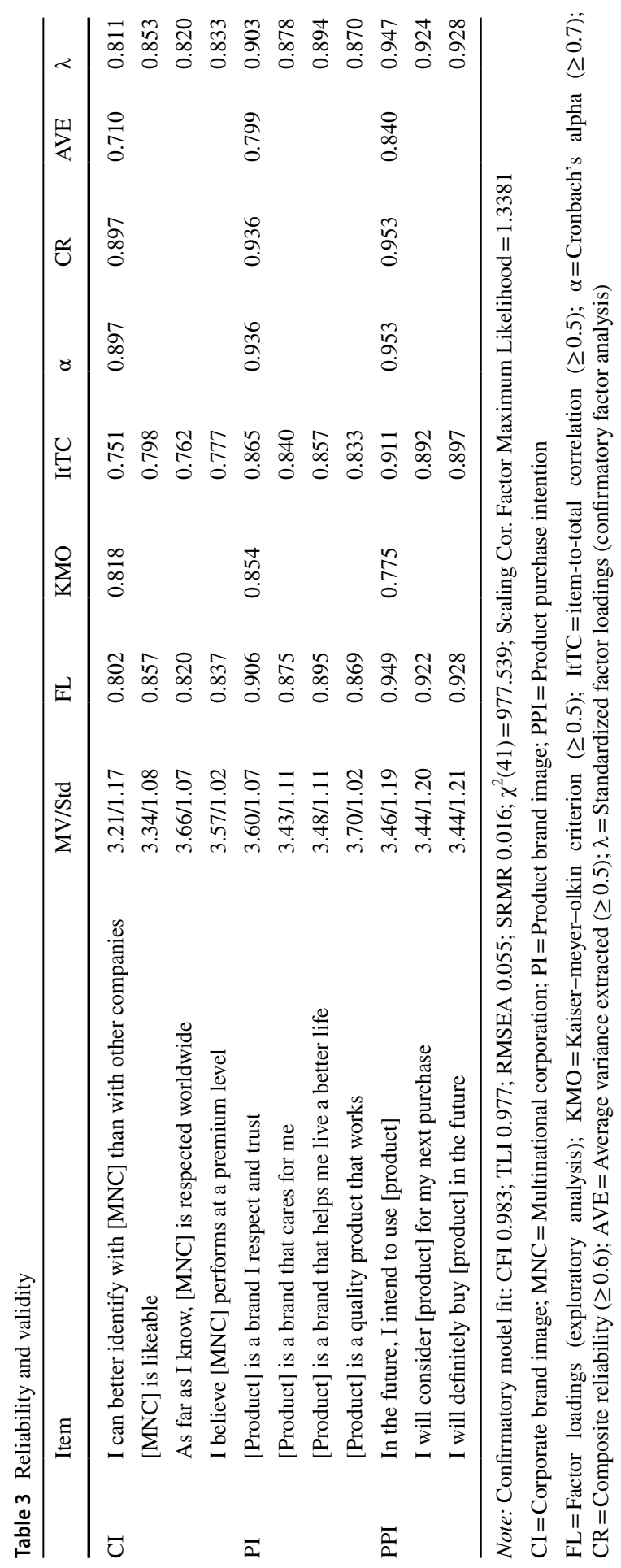


Discriminant validity between product brand image and purchase intention was ensured by Anderson and Gerbing's test $\left(1988, \chi^{2}(2)=438.073, p<0.001\right.$, Table 4; correlation exceeds 0.800 , Table 5). Multilevel reliability was confirmed based on multilevel alpha, multilevel composite-, and maximal reliability (Geldhof et al., 2014, Table 6). After comparing the validity coefficients of factor score procedures (based on factor variances, Table 7), regression scores were used for corporate and product brand image to reduce model complexity (DiStefano et al., 2009; Kline, 2015, pp. 127-129).

An appropriate questionnaire design was applied (i.e., ensuring the anonymity and confidentiality of the study, appropriate order of questions, Chang et al., $2010)$ to ex ante address potential threats of common method variance (CMV). Ex post, a single-factor test showed significant lower fit values than the proposed model $\left(\Delta \chi^{2}(6)=10,505.107, p<0.001\right)$. The marker variable technique was applied with occupation as a theoretically unrelated marker variable (Lindell \& Whitney, 2001). It revealed no significant changes in correlations, and the method variances were less than 2.0\% (Williams et al., 2010). CMV is not an issue in this study (see Web Appendix A).

Endogeneity tests reveal bias from omitted variables (Antonakis et al., 2014). MNCs' perceived brand innovativeness of the corporation was selected as a theoretically related instrumental variable (IV, one item, Shams et al., 2015) for corporate brand image. After ensuring the IV's strength using a F-test (Stock \& Watson, 2019, p. 270), an efficient model was calculated. It did not differ significantly from the consistent model (Hausman, 1978), demonstrating that corporate brand image is exogenous (see Web Appendix B).

Measurement invariance (MI) was tested between every country: metric invariance was achieved (Steenkamp \& Baumgartner, 1998, see Web Appendix C). Multilevel measurement invariance was tested following the procedure of Jak et al. (2013), which is applicable to a large number of groups. All factor loadings were considered equal across levels. For the second product (fourth corporate) brand image item, $3.55 \%$ (3.43\%) of the total variance is caused by cluster bias. MI is not a serious problem in this study.

Table 4 Discriminant validity

\begin{tabular}{llll}
\hline & CI & PI & PPI \\
\hline CI & 0.710 & 0.552 & 0.422 \\
PI & $0.743^{* * *}$ & 0.799 & 0.763 \\
PPI & $0.650^{* * *}$ & $0.874 * * *$ & 0.840 \\
\hline
\end{tabular}

$* p<0.05 ; * * p<0.01 ; * * * p<0.001 ; \mathrm{ns}=$ not significant

Confirmatory Model Fit: CFI 0.983; TLI 0.977; RMSEA 0.055; SRMR 0.016; $\chi^{2}(41)=977.539$; Scaling Cor. Factor Maximum likelihood=1.3381

Note: $\mathrm{CI}=$ Corporate brand image; $\mathrm{PI}=$ product brand image; $\mathrm{PPI}=$ Product purchase intention

AVE $=$ Average variance extracted $(\geq 0.5)$; AVEs are on the diagonal; squared correlations are above the diagonal; correlations are below the diagonal 


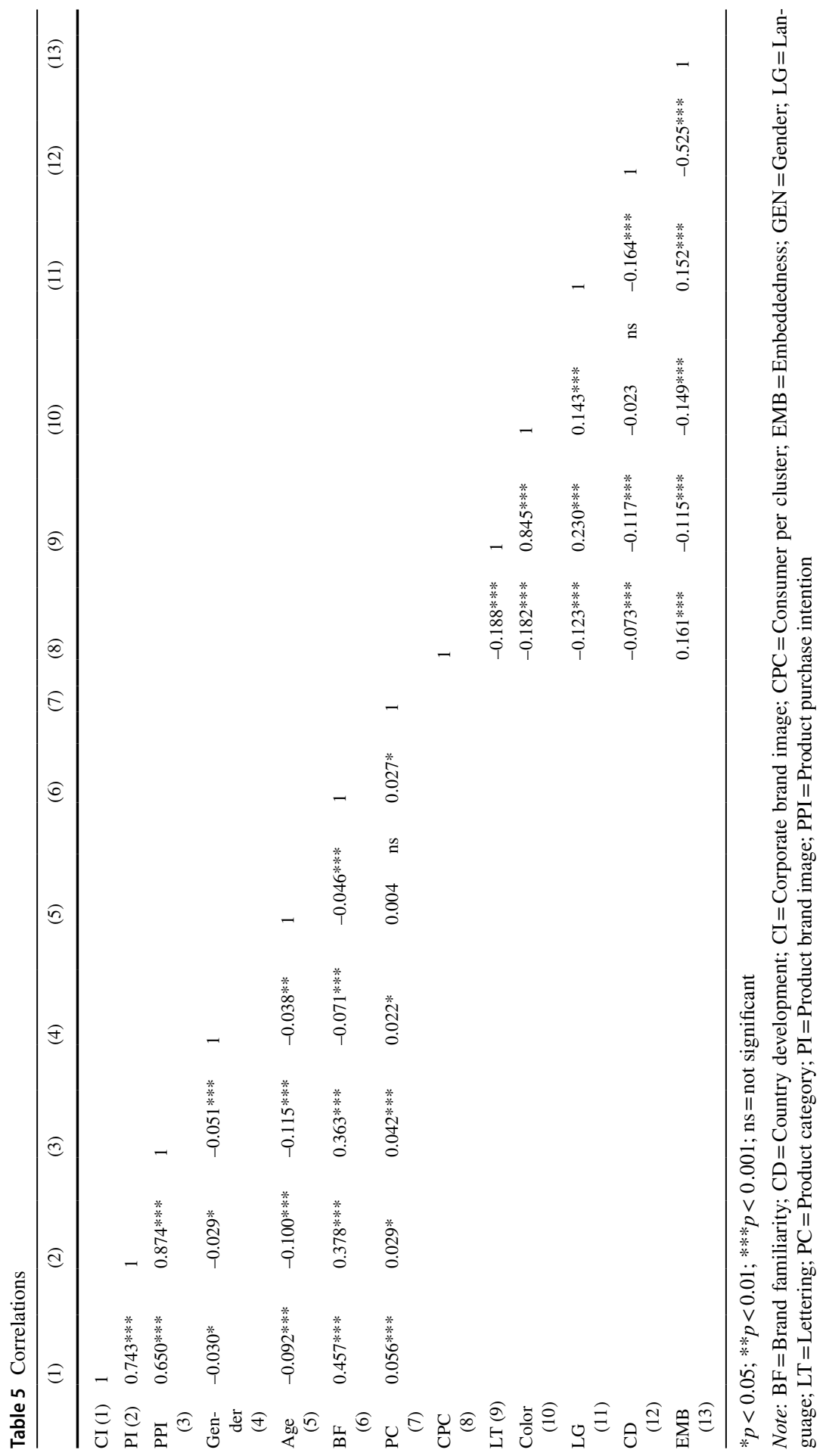


Table 6 Multilevel reliability

\begin{tabular}{|c|c|c|c|c|c|c|}
\hline & \multicolumn{2}{|l|}{ Alpha } & \multicolumn{2}{|c|}{ Composite reliability } & \multicolumn{2}{|c|}{ Maximal reliability } \\
\hline & $\alpha_{\mathrm{W}}$ & $\alpha_{\mathrm{B}}$ & $\omega_{\mathrm{W}}$ & $\omega_{\mathrm{B}}$ & $\mathrm{H}_{\mathrm{W}}$ & $\mathrm{H}_{\mathrm{B}}$ \\
\hline CI & 0.888 & 0.977 & 0.889 & 0.986 & 0.891 & 0.988 \\
\hline PI & 0.936 & 0.972 & 0.930 & 0.989 & 0.931 & 0.992 \\
\hline PPI & 0.947 & 0.992 & 0.948 & 0.992 & 0.949 & 0.994 \\
\hline
\end{tabular}

Table 7 Comparison of factor scores

\begin{tabular}{lll}
\hline & Regression scores validity coefficients & Item parceling validity coefficients \\
\hline CI & 0.900 & 0.898 \\
PI & 0.937 & 0.907 \\
\hline
\end{tabular}

\subsection{Method}

MSEM was applied using Mplus 8.3 to test the hypotheses. MSEM accounts for the nested data structure by considering individual- and country-level variables and the interactions between them. It detects observed variances between and within countries and specifies latent variables and moderators (Hox et al., 2018, pp. 271-274).

The analysis was based on calculating random intercept and slope models in a stepwise procedure (Hox et al., 2018, pp. 9-13). First, a baseline model including individual-level controls was calculated. We added corporate and product brand image as predictor variables. Due to model complexity, the independent variables and all moderators were grand mean centered (Ryu, 2015). The level-one model is as follows:

$$
P P I_{i j}=\beta_{0 j}+\beta_{1 j}\left(C I_{i j}\right)+\beta_{2 j}\left(P I_{i j}\right)+\beta_{\text {controls }} I L C_{i j}+r_{i j},
$$

where $i$ indicates consumers in a country and $j$ displays the countries. $P P I_{i j}$ represents consumer $i$ 's product purchase intention in country $j . C I_{i j}$ and $P I_{i j}$ represent consumer $i$ 's perceived corporate and product brand image in country $j . I L C_{i j}$ denotes individual-level control variables. The first-level intercept $\beta_{0 j}$ and the individual-level slopes $\beta_{1 j}$ and $\beta_{2 j}$ are allowed to vary across countries. $r_{i j}$ represents the individual-level error term.

Second, we included country-level controls (second baseline model) and countrylevel moderators:

$$
\begin{gathered}
\beta_{0 j}=\gamma_{00}+\gamma_{01}\left(C L V_{j}\right)+\gamma_{02}\left(C L C_{j}\right)+u_{0 j}, \\
\beta_{1 j}=\gamma_{10}+\gamma_{11}\left(C L V_{j}\right)+u_{1 j}, \\
\beta_{2 j}=\gamma_{20}+\gamma_{21}\left(C L V_{j}\right)+u_{2 j},
\end{gathered}
$$


with $\gamma_{00}$ denoting the county-level intercept of product purchase intention, $\gamma_{10}$ and $\gamma_{20}$ representing the intercepts of the country-level random slope of corporate and product brand image. $C L V_{j}$ displays the different country-level moderator variables (i.e., the degree of country development and embeddedness). $C L C_{j}$ denotes the country-level control variables (i.e., number of consumers per cluster, lettering, color, and language). For each moderator, we calculated a separate model to predict variations in $\beta$ coefficients. Comprising Eqs. (1-4), the following equation represents the multilevel moderated mediation with cross-level interactions:

$$
\begin{aligned}
P P I_{i j}= & \gamma_{00}+\gamma_{01}\left(C L V_{j}\right)+\gamma_{10}\left(C I_{i j}\right)+\gamma_{11}\left(C L V_{j}\right)\left(C I_{i j}\right)+\gamma_{20}\left(P I_{i j}\right) \\
& +\gamma_{21}\left(C L V_{j}\right)\left(P I_{i j}\right)+\gamma_{I L C} I L C_{i j}+\gamma_{C L C} C L C_{i j}+\text { error }
\end{aligned}
$$

For hypotheses testing, we used cross-level interaction effects and conditional indirect and direct effects according to the floodlight test (Hayes, 2017, p. 254). This test shows at which degrees of the moderator's measurement span the conditional effect yields strengthened or weakened significant results. It adds significant value compared to previous tests as it considers all moderator values instead of specific ones (Spiller et al., 2013).

\section{Results}

The results of the hypotheses tests are shown in Table 8. Unstandardized coefficients are interpreted as standardized coefficients cannot be computed in random intercept and slopes models (Hox et al., 2018, pp. 17-18).

There is a positive indirect effect of global corporate brand image via global product brand image on product purchase intention $(b=0.603, p<0.001)$. The results also indicate a positive direct link between global corporate brand image and product purchase intention $(b=0.062, p<0.001)$ : the indirect (versus direct) effect is significantly stronger $(b=0.541, p<0.001)$. Hypotheses $1 a-c$ are supported.

The degree of country development positively moderates the indirect effect of global corporate brand image through global product brand image on product purchase intention $\left(b_{\mathrm{PI} \times \mathrm{CD} \rightarrow \mathrm{PPI}}=0.469, p<0.001\right)$. Hypothesis $2 a$ is supported. An increasing degree of country development diminishes the direct effect of global corporate brand image $\left(b_{\mathrm{CI} \times \mathrm{CD} \rightarrow \mathrm{PPI}}=-0.295, p<0.05\right)$, which supports hypothesis $2 b$. Figure 2 supports these results. An increasing degree of country development enhances the positive indirect effect of global corporate brand image but diminishes the direct effect. With very high degrees of country development, even the positive direct effect of corporate brand image on product purchase intention becomes insignificant (the lower confidence interval crosses the $\mathrm{x}$-axis). The global product brand gains, while the global corporate brand loses, importance with an increasing degree of country development. Twenty percent of the country-level variance is explained.

The degree of embeddedness positively moderates the indirect effect of global corporate brand image on product purchase intention $\left(b_{\mathrm{PI} \times \mathrm{EMB} \rightarrow \mathrm{PPI}}=0.147\right.$, $p<0.001$ ), which supports hypothesis 3a. Conditional indirect effects support this 


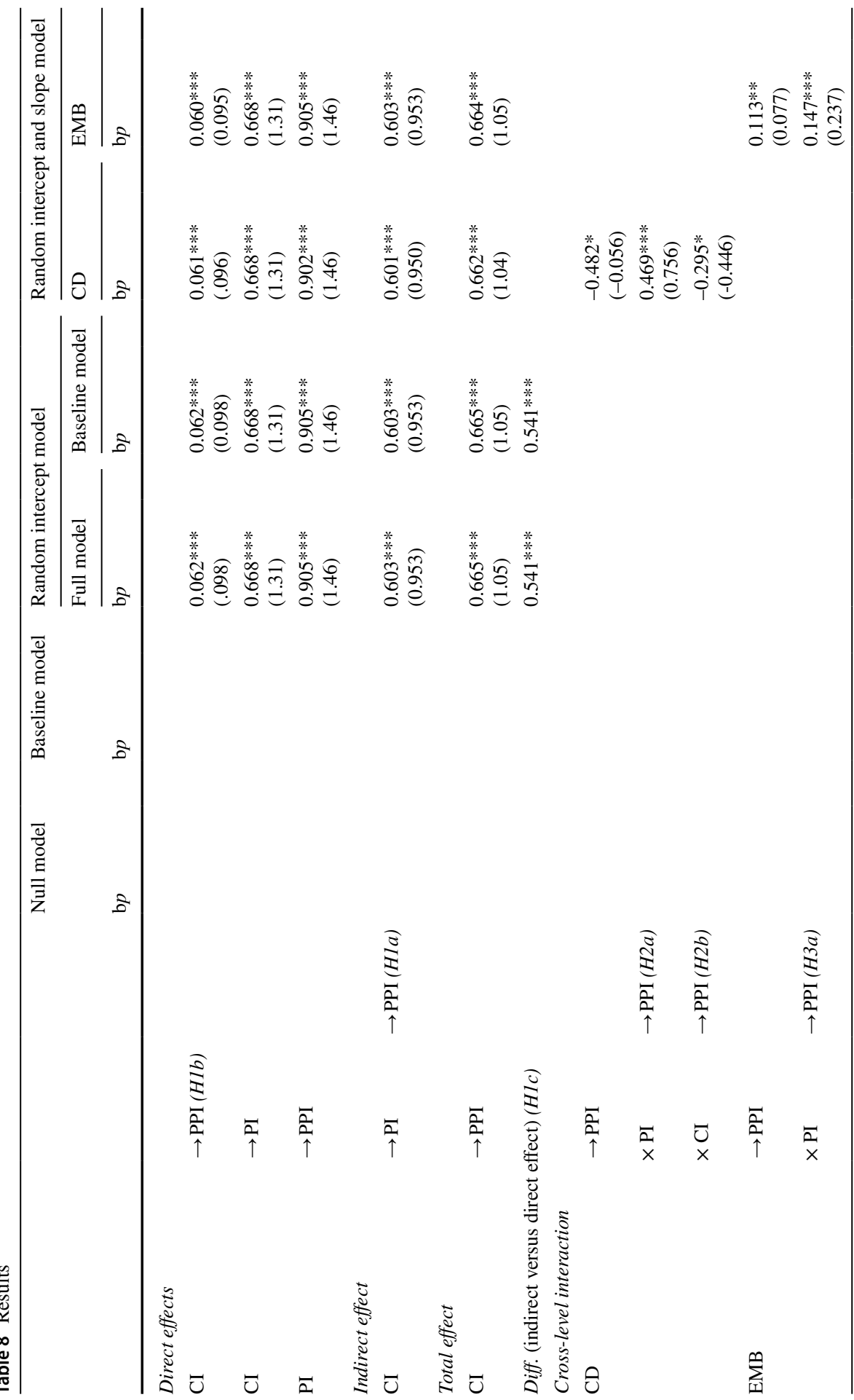




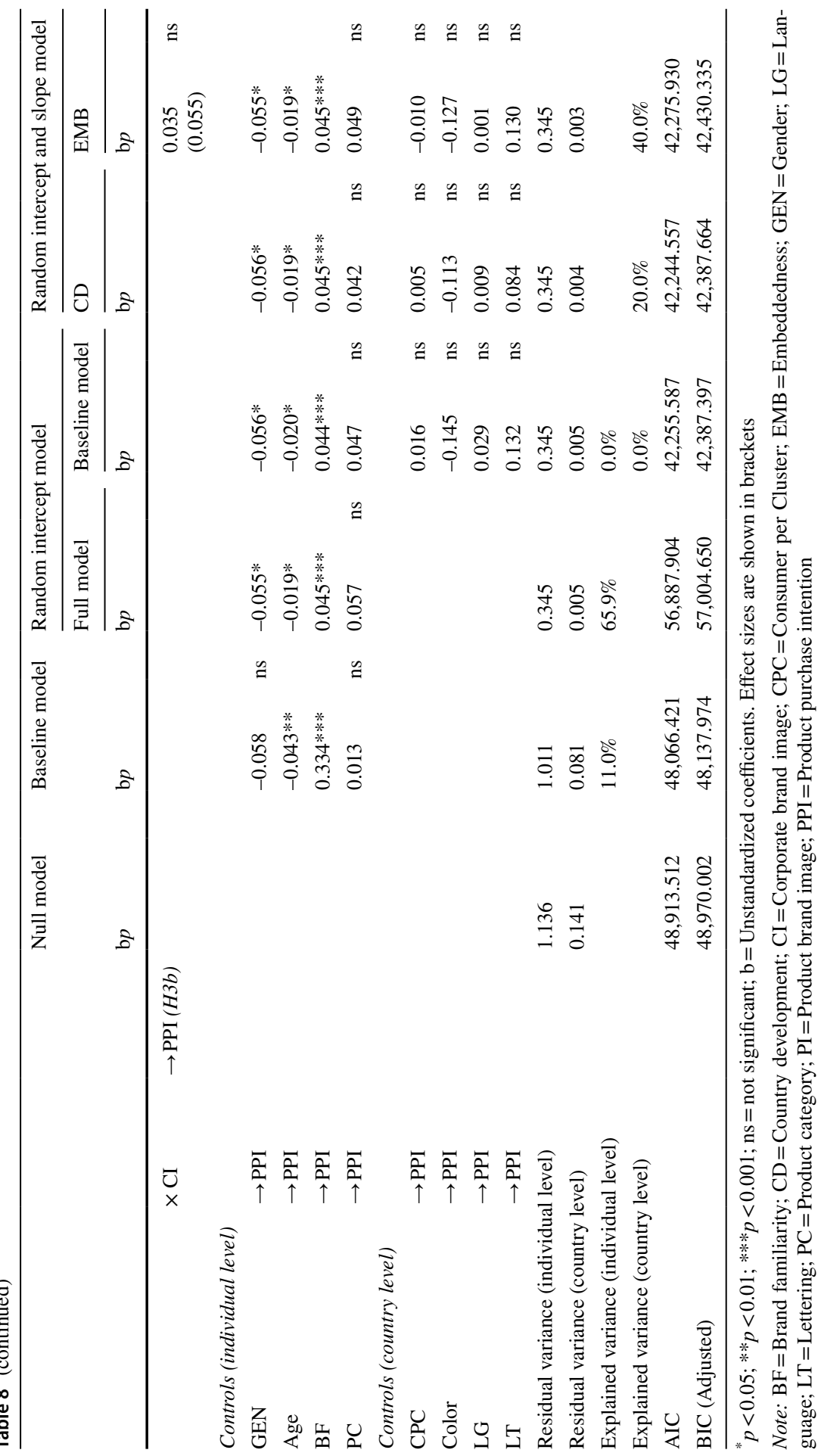




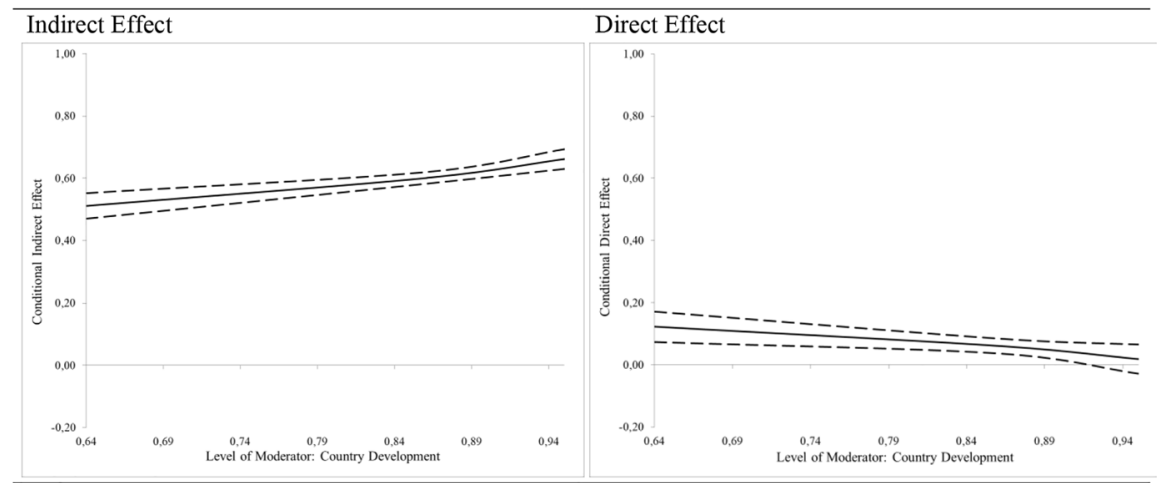

Notes: Plots based on unstandardized coefficients. Continuous lines represent the indirect and direct paths at several levels of moderator values. Dashed lines represent the confidence bands. Indirect and direct paths are significant as long as the dashed lines do not cross the $\mathrm{x}$-axis.

Fig. 2 Conditional indirect and direct effect for country development

hypothesis, as an increasing degree of embeddedness enhances the effect of the endorsed branding strategy (see Fig. 3). However, embeddedness does not significantly affect the direct effect of global corporate brand image on product purchase intention $\left(b_{\mathrm{CI} \times \mathrm{EMB} \rightarrow \mathrm{PPI}}=0.035, p>0.05\right)$. Thus, hypotheses $3 b$ is rejected. Consumers in highly embedded societies with more homogeneous brand schemata (Shaw, 1990) rely on product (versus corporate) brand schemata in product purchase situations. Moreover, the global corporate brand appears to receive importance only when endorsing MNCs' global product brands as this strategy is consistent with consumers' cultural values (Schwartz, 1994). However, Fig. 3 shows that only for very low levels of embeddedness does the direct effect of global corporate brand image on product purchase intention become insignificant (the lower confidence interval crosses the $\mathrm{X}$-axis). Embeddedness moderates the indirect effect of corporate brand image via the product brand image on product purchase intention but only partially moderates the direct effect. Forty percent of the country-level variance is explained.

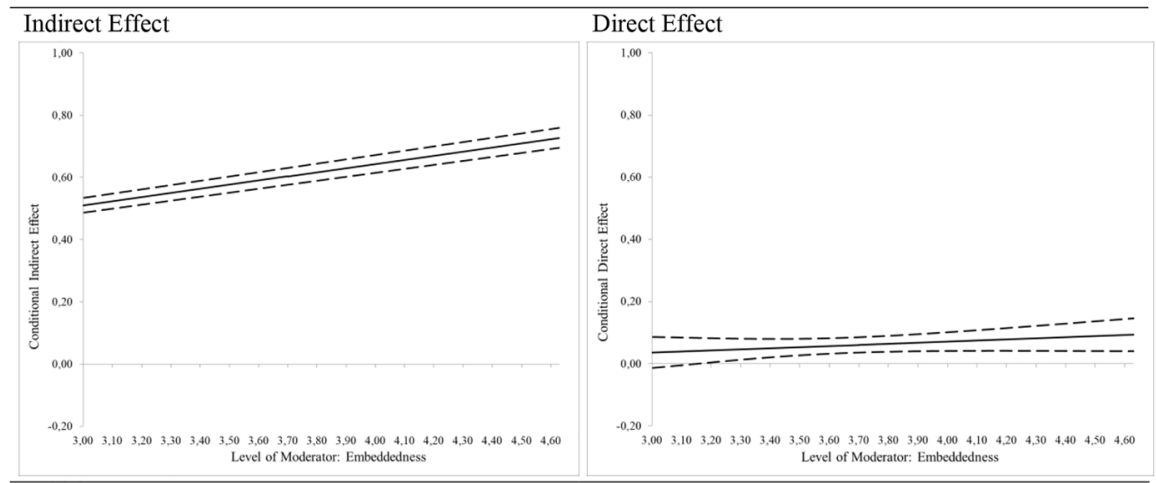

Notes: Plots based on unstandardized coefficients. Continuous lines represent the indirect and direct paths at several levels of moderator values. Dashed lines represent the confidence bands. Indirect and direct paths are significant as long as the dashed lines do not cross the $\mathrm{x}$-axis.

Fig. 3 Conditional indirect and direct effect for embeddedness 
Among the covariates, gender, age, and brand familiarity have significant and expected effects.

\subsection{Alternative Models}

For reasons of stability, a random split-half test was applied (ensuring multilevel reliability, Geldhof et al., 2014). The indirect and direct effect of global corporate brand image on product purchase intention remained stable (see Web Appendix D). Three alternative models were considered (see Web Appendix E).

First, we changed the dependent variable to provide insight into the effects on purchase intention regarding the MNC (measured by four items, Putrevu \& Lord, 1994). This procedure shows a dependence of schema activation on respective purchase situations. In purchase situations, in which consumers have purchase intentions towards an MNC, we assume consumers will primarily activate respective global corporate brand schemata. The results support this rationale and show a positive indirect $(b=0.138, p<0.001)$ and direct $(b=0.735, p<0.001)$ effect of the endorser: the direct effect is significantly stronger $(b=0.597, p<0.001)$. The corporate brand gains, whereas the endorsed branding strategy loses, importance when purchase intention towards the corporation (versus product) is considered. Thus, whether and how corporate and product brand schemata are activated to determine consumers' purchase intention depends on the respective purchase situation.

Second, we test corporate brand image as a mediator and product brand image as an antecedent. Schema theory assumes that subordinated product brand schemata affect superordinated corporate brand schemata when determining product purchase intention (Crocker, 1984). The rationale aligns with our results (direct: $b=0.903$, $p<0.001$, indirect: $b=0.045, p<0.001$ ), supporting the assumption of global corporate brand schemata being less important in global product purchase situations. Moreover, model fit was worse than for our proposed model (based on comparison of $\mathrm{AIC} / \mathrm{BIC})$.

Third, a feedback loop between product and corporate brand is possible (Heinberg et al., 2018). Based on schema theory, product and corporate brand schemata in consumers' minds affect each other in a loop and affect product purchase intention. Even though global corporate and product brand schemata influence each other, the activation of product-related schemata should be primarily relevant in product purchase situations (Biehal \& Sheinin, 2007). A nonrecursive MSEM with two appropriate IVs and a required disturbance correlation between the images was applied (Nagase \& Kano, 2017). First, social and environmental responsibility (measured by three items, Walsh et al., 2009) was selected as the IV because it is known to be a strong predictor of corporate brand image (Iglesias et al., 2019). Second, product attributes (two items, Souiden et al., 2006) were selected as the IV as they are known to be core antecedents of product brand image (Plumeyer et al., 2019). The results support our observations and show that global corporate and product brand image influence each other $\left(b_{\mathrm{CI} \rightarrow \mathrm{PI}}=0.231, p<0.001 ; b_{\mathrm{PI} \rightarrow \mathrm{CI}}=0.374, p<0.001\right)$. Even when considering the reciprocal effects, product-related schemata are primarily relevant for product purchase intention (total effects: $b_{\mathrm{CI} \rightarrow \mathrm{PPI}}=0.268, p<0.001$ 
and $b_{\mathrm{PI} \rightarrow \mathrm{PPI}}=0.929, p<0.001$; direct effects: $b_{\mathrm{CI} \rightarrow \mathrm{PPI}}=0.058, p<0.001$ versus $\left.b_{\mathrm{PI} \rightarrow \mathrm{PPI}}=0.907, p<0.001\right)$. This model has a worse fit than our proposed model (comparing $\mathrm{AIC} / \mathrm{BIC}$ ).

\section{Discussion}

This study contributes to our understanding of whether and how MNCs can benefit from an endorsed branding strategy of global brands across nations (contributing to respective calls, e.g., Brexendorf \& Keller, 2017; Samiee, 2019). Furthermore, we enhance the literature by analyzing the effects of endorsed branding depending on important boundary conditions: the degree of country development and national culture (Gürhan-Canli et al., 2018). Next, we carefully provide theoretical and managerial implications.

\subsection{Theoretical Implications}

Regarding our first research question, the results show an indirect and direct effect of global corporate brand image through global product brand image on product purchase intention. The indirect effect more strongly affects product purchase intention across nations, and MNCs benefit from the use of endorsed branding. These findings confirm the applicability of the rationale of schema theory in the context of global brands across nations (Crocker, 1984; Halkias, 2015). Consumers intending to purchase global product brands primarily activate product brand schemata (supporting national studies, Biehal \& Sheinin, 2007). Through an endorsed branding strategy, the superordinated corporate brand schema adds value to the subordinated product brand schema, which subsequently results in strong purchase intention towards global product brands. We thereby empirically confirm that hierarchically structured brand schemata are linked to the success of specific branding strategies (Halkias, 2015). The use of this strategy enhances firm value (Hsu et al., 2016), reduces challenges of brand extensions (He et al., 2016), and improves consumers' purchase intention across nations. These findings are in line with, but extend, most studies on the relationship of corporate and product evaluations. We contribute to the literature on the benefits of vertical image transfer (celebrity endorsement as a communication issue, e.g., Derdenger, 2018; Chen \& Wyer Jr, 2020; brand extension, e.g., Allman et al., 2016; Muroyiwa et al., 2017) by showing the indirect effect of global corporate brand image across nations.

Regarding our second research question, we respond to research calls by analyzing two important national boundary conditions (e.g., Gürhan-Canli et al., 2018; Heinberg et al., 2018).

First, we enhance the current research by accounting for the indirect and direct effects of global corporate brand image based on the degree of country development (following calls, Wang et al., 2017). The degree of country development is of paramount importance because globalization forces MNCs to succeed, particularly in emerging markets with strong economic growth prospects and branding 
strategy challenges for some of them (e.g., Gupta \& Wright, 2019; He \& Wang, 2017). The results underscore our theoretical rationale and enhance knowledge on how brand schemata vary due to environmental differences (Halkias, 2015). The degree of country development affects the underlying cognitive processes of global brand schemata development and activation (Puligadda et al., 2012). Consumers in emerging versus developed countries rely on either global product or corporate brand schemata in product purchase situations. Countries with an increasing degree of country development represent a setting where product (versus corporate) brand information is particularly relevant (Hsieh et al., 2004). Well-structured brand schemata of brand-schematic consumers further facilitate and thus enhance the image transfer from superordinated corporate to subordinated product brand schemata. Hence, for endorsed branding, the ease of brand schema activation and linkage increases with an increasing degree of country development. In contrast, the lower brand knowledge of more brand-aschematic consumers affects cognitive information processing (Heinberg et al., 2017) and increases the importance of global corporate brand schema, even in product purchase situations. In less developed countries, complex endorsed branding strategies cannot easily be cognitively processed. Direct corporate brand effects gain, while indirect image transfer effects lose, importance. These findings confirm indications from studies in emerging markets (Heinberg et al., 2018). We also contribute to the endorsed branding research across nations by providing insightful conditional effects.

Second, it is important for MNCs to observe the role of national culture as we identify a significant role of the value dimension embeddedness in the indirect effect of global corporate brand image. This finding confirms our theoretical rationale and delivers respective insights on why brand schemata differ between countries (Halkias, 2015). Embeddedness affects consumers' brand schematicity and how their schemata are structured (Crocker, 1984). In countries that score high on embeddedness, consumers' cognitive schema structure is more homogeneous (Shaw, 1990), which makes schemata easier to activate. Thus, for individuals, it is easier to activate global corporate and product brand schemata and transfer corporate to product brand image when intending to purchase global product brands. Moreover, the application of the endorsed branding strategy appears to meet the needs of belongingness of individuals in highly embedded societies and aligns with their values (Schwartz, 1994) as the global corporate and global product brand deliver the feeling of being part of the community and gaining status. Unfortunately, the theory cannot explain the insignificant moderating effect on the direct link between global corporate brand image and product purchase intention in our model. Hence, future research may apply further theories (e.g., Heinberg et al., 2018; Steenkamp, 2019a). However, we align with and contribute to the findings of country comparisons indicating a stronger valuation of corporate endorsers in societies that value the group (Jakubanecs \& Supphellen, 2012). We go beyond those studies and shed light on ambiguous results in the global brand literature and cultural contexts (Van der Lans et al., 2016). Finally, we show cross-level interactions of embeddedness and thus underscore the need to analyze national cultural differences. 
We could even speculate that the positive image transfer effects in highly developed and embedded countries may differ when (un)favorable corporate brand schemata are linked to (un)favorable product brand schemata (Kirca et al., 2020). As product brands receive more attention in such countries, we would expect favorable product brand images to level unfavorable corporate brand images. In contrast, unfavorable product brand images would probably weaken favorable corporate brand images.

Finally, we draw theoretical conclusions by providing a country portfolio with respect to the degree of country development and embeddedness as moderators of endorsed branding effects (see Fig. 4). Based on the stronger indirect (versus direct) effect, we carefully recommend the application of an endorsed branding strategy across nations (instead of relying solely on the product or corporate brand; Brexendorf \& Keller, 2017). However, MNCs must adjust the strategy according to the development and cultural conditions in countries and face tradeoffs. The country portfolio may serve as a basis for further research and management regarding the relative effect of endorsed branding, even for countries not analyzed but with available country development and embeddedness data.

Field I: The indirect effect of global corporate brand on product purchase intention is enhanced by an increasing degree of country development and embeddedness. Individuals in such countries primarily rely on product brand schemata in product purchase situations (Hsieh et al., 2004). They also activate and link the superordinated corporate brand schema to the subordinated product brand schema when intending to purchase global product brands. We highly recommend the use of the endorsed branding strategy in countries within this quadrant. Consumers should

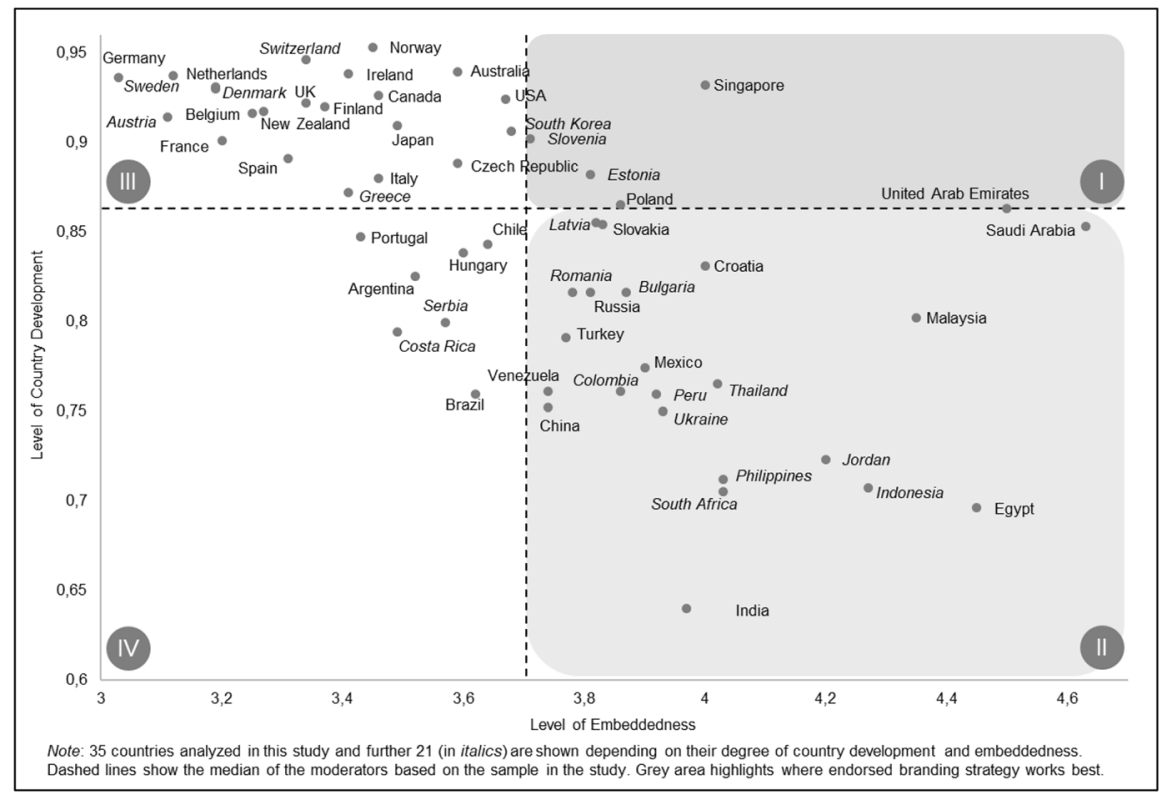

Fig. 4 Country portfolio 
be able to identify the product with the MNC as this strategy is beneficial in terms of consumer behavior (in addition to increased firm value, Hsu et al., 2016). Thus, we encourage MNCs to use corporate brand names/logos to endorse specific product brands whereas the product brand should still be more visible (Brexendorf \& Keller, 2017).

Field II: The strong indirect effect of corporate brand image on product purchase intention is diminished by lower levels of country development and reinforced by a high degree of embeddedness. Embeddedness is the stronger lever (explaining forty percent versus twenty percent of variance) for determining endorsed branding effects. Thus, we recommend the careful use of the endorsed branding strategy in such countries. Especially in countries close to the country development threshold (e.g., Saudi Arabia), endorser branding can be beneficial but should be combined with some marketing activities. In countries distant from the threshold (e.g., India), the global corporate brand may be focused. MNCs could enlarge the corporate brand name/logo on the product brand or apply some form of sub-branding (Åsberg \& Uggla, 2019).

Field III: Higher levels of country development enhance, while lower levels of embeddedness diminish, the benefits of the endorsed branding strategy in terms of consumer behavior, an opposite context to Field II. MNCs should avoid or very carefully manage existent endorsed branding strategies in such (mainly European) countries. On the one hand, when applying the endorsed branding strategy, further marketing activities are needed, e.g., communication. On the other hand, MNCs could shift the focus to the global product brand. Hence, global brand managers may decrease the size of the corporate brand name/logo or even place it on the back of the product package (like companies employing the house of brands strategy, Hsu et al., 2016).

Field IV: The effect of the endorsed branding strategy is diminished by both lower country development and embeddedness. The application of the endorsed branding strategy is not recommended in this context or may need many and strong additional marketing-mix efforts. The application of the branded house strategy may be more promising.

In summary, endorsed branding is successful in countries in Field I and Field II (the direct effect of global corporate brand image on product purchase intention gains importance in Fields II/IV). Lower levels of country development increase the benefits of focusing on the corporate brand image in product purchase situations (product brand becomes less attractive, Bahadir et al., 2015), whereas only high levels of embeddedness appear to play a minor role. Thus, we recommend that the global corporate brand should be emphasized in countries such as India and Argentina. Moreover, consumers in more developed countries primarily rely on global product brand schemata in product purchase situations (Hsieh et al., 2004). We conclude that for consumers who live in highly developed but less embedded countries, a more product-focused branding strategy may be better (e.g., house of brands strategy, Hsu et al., 2016). Future research may compare respective effects across nations. 


\subsection{Managerial Implications}

Managers can benefit from an endorsed branding strategy across nations. They may follow L'Oréal, Nestlé, or Unilever and increasingly use endorsed branding as a source of competitive advantage abroad. Focusing on product brands is advantageous to enhance product purchase intention (Hsieh et al., 2004). Moreover, promoting the corporate brand as an endorser leads to stronger consumer responses across nations. It is highly recommendable to make the global corporate brand visible to create positive spillover effects. This provides reassurance for consumers in product purchase situations and enables managers to monitor their brands (Khojastehpour \& Johns, 2015). Consequently, managers profit from demand- and supply-side benefits (Hsu et al., 2016).

However, the country context yields further implications (Heinberg et al., 2018). The degree of country development and national culture are important levers of the effects of endorsed branding. Kellogg's, for example, considers the strengths of the endorsed branding strategy but adjusts it in Europe (Kellogg's, 2019). Our country portfolio shows options for centrally managed endorsed branding and offers concrete choices for managers (see Fig. 4).

- Managers should clearly apply the endorsed branding strategy in countries in Field I because here MNCs profit most from the strategy. Thus, managers should build strong global corporate and product brands and promote the linkage between those brand schemata. Additionally, in Field II, we recommend endorsed branding in tendency. Here, managers can also rely on the global corporate endorser itself (generally in less developed countries) or on a more corporate brand focused mixed branding strategy, such as sub-branding (Hsu et al., 2016). They are confronted with only weak cognitive brand schemata and should focus on market creation (Sheth, 2011) to strengthen strong global corporate brands in consumers' minds to make the connection more salient for decision-making.

- In the context of Fields III and IV, the effects of endorsed branding are diminished and managers must invest in further marketing-mix activities. In doing so, they may use more product-dominant strategies (Field III) as consumers in such countries favor the global product brand. In contrast, they may apply the branded house strategy and communicate and rely on the global corporate endorser itself (Field IV), as these effects are positively levered in countries with lower degrees of development and may be a starting point to gain market share in important emerging markets (He \& Wang, 2017; especially when facing unbranded competition, Bahadir et al., 2015).

These implications constitute a starting point for internationalization when entering new countries and deciding whether to apply endorsed branding within new country openings. 


\section{Limitations and Further Research}

This study has certain limitations that suggest future research directions.

Although we carefully collected specific data, database expansion will allow further conclusions, e.g., by analyzing additional MNCs, industries, product categories or even local brands (Davvetas \& Diamantopoulos, 2016; ensuring presence along nondurable-durable or price continuums, Özsomer, 2012). The study's cross-national design improves its external validity while future research may place emphasis on internal validity (e.g., Halkias et al., 2016). Moreover, this study includes more developed than emerging countries while within a balance of least developed and emerging countries, a weaker (stronger) indirect (direct) effect of global corporate brand image via product brand image on product purchase intention should emerge.

Regarding the measurement, we rely on brand images as important constructs to assess consumers' schemata. However, there is no consensus on how to measure image (e.g., Plumeyer et al., 2019; Souiden et al., 2020). Established measures, e.g., brand equity (Keller, 1993), can be applied to replicate our results and to provide additional insights into the interplay between the corporate and product brand (Heinberg et al., 2018). Moreover, global corporate and product brand image may vary over time and may be different from those for local brands. We controlled for brand familiarity but studies could additionally view further variables (e.g., product category involvement, Strizhakova et al., 2011). Qualitative research allows for the development of emic, country-specific measures, which may enhance construct equivalence assessment (Ford et al., 2018). Due to the high number of countries surveyed and the resulting need for item comparability, we use slightly modified imposed etic and previously used scales (Douglas \& Craig, 2006; Yang et al., 2019).

Regarding our conceptual framework, scholars might study further branding strategies across nations, e.g., sub-branding or variations of endorsed branding (also different placements of the corporate on the product brand, Brexendorf \& Keller, 2017; Hsu et al., 2016). Moreover, studying different modes of communication of corporate brands, temporal endorsed or co-branding could be promising (Åsberg \& Uggla, 2019). Future studies could also account for the combined effects of endorsed branding and celebrity endorsement (as an effective communication tool, Dwivedi et al., 2014). The positive effects of endorsed branding can be enhanced by celebrity endorsers as respective attributes can be easily integrated into existing matching brand schemata (Knoll \& Matthes, 2017). They may also study the effects of schematic constructs (e.g., attributes within a schema, schema activation or favorability, Halkias, 2015). Finally, the role of further cultural value dimensions or contextual factors on global endorsement might be studied (e.g., social media usage, political ideology, Gürhan-Canli et al., 2018). 


\section{Notes}

[1] We do not consider the subtypes of branding strategies such as brand alliances or co-branding (Åsberg \& Uggla, 2019).

[2] Missing embeddedness data for two countries (UAE, SAU) were replaced by the values of neighboring countries according to Steenkamp and Geyskens (2006). We estimated models without those countries with stable results. For reasons of complexity and model identification, we included the two countries in the survey.

Supplementary Information The online version contains supplementary material available at https://doi. org/10.1007/s11575-021-00450-1.

Funding Open Access funding enabled and organized by Projekt DEAL.

Availability of data and material None.

Code availability None.

Declarations

Conflicts of interest None.

Open Access This article is licensed under a Creative Commons Attribution 4.0 International License, which permits use, sharing, adaptation, distribution and reproduction in any medium or format, as long as you give appropriate credit to the original author(s) and the source, provide a link to the Creative Commons licence, and indicate if changes were made. The images or other third party material in this article are included in the article's Creative Commons licence, unless indicated otherwise in a credit line to the material. If material is not included in the article's Creative Commons licence and your intended use is not permitted by statutory regulation or exceeds the permitted use, you will need to obtain permission directly from the copyright holder. To view a copy of this licence, visit http://creativecommons.org/licen ses/by/4.0/.

\section{References}

Abbey, J. D., \& Meloy, M. G. (2017). Attention by design: Using attention checks to detect inattentive respondents and improve data quality. Journal of Operations Management, 53(November), 63-70.

Abosag, I., \& Farah, M. F. (2014). The influence of religiously motivated consumer boycotts on brand image, loyalty and product judgment. European Journal of Marketing, 48(11/12), 2262-2283.

Ahn, J., Park, J. K., \& Hyun, H. (2018). Luxury product to service brand extension and brand equity transfer. Journal of Retailing and Consumer Services, 42, 22-28.

Allman, H. F., Fenik, A. P., Hewett, K., \& Morgan, F. N. (2016). Brand image evaluations: The interactive roles of country of manufacture, brand concept, and vertical line extension type. Journal of International Marketing, 24(2), 40-61.

Allman, H. F., Hewett, K., \& Kaur, M. (2019). Understanding Cultural Differences in Consumers' Reactions to Foreign-Market Brand Extensions: The Role of Thinking Styles. Journal of International Marketing, 27(2), 1-21.

Anderson, J. C., \& Gerbing, D. W. (1988). Structural equation modeling in practice: A review and recommended two-step approach. Psychological Bulletin, 103(3), 411-423. 
Antonakis, J., Bendahan, S., Jacquart, P., \& Lalive, R. (2014). Causality and endogeneity: Problems and solutions. In D. V. Day (Ed.), The Oxford handbook of leadership and organizations (pp. 93-117). Oxford University Press.

Åsberg, P., \& Uggla, H. (2019). Introducing multi-dimensional brand architecture: Taking structure, market orientation and stakeholder alignment into account. Journal of Brand Management, 26(5), $483-496$.

Bahadir, S. C., Bharadwaj, S. G., \& Srivastava, R. K. (2015). Marketing mix and brand sales in global markets: Examining the contingent role of country-market characteristics. Journal of International Business Studies, 46(5), 596-619.

Bian, X., \& Moutinho, L. (2011). The role of brand image, product involvement, and knowledge in explaining consumer purchase behaviour of counterfeits. European Journal of Marketing, 45(1/2), $191-216$.

Biehal, G. J., \& Sheinin, D. A. (2007). The influence of corporate messages on the product portfolio. Journal of Marketing, 71(2), 12-25.

Boisvert, J., \& Ashill, N. J. (2018). The impact of branding strategies on horizontal and downward line extension of luxury brands. International Marketing Review, 35(6), 1033-1052.

Brexendorf, T. O., \& Keller, K. L. (2017). Leveraging the corporate brand: The importance of corporate brand innovativeness and brand architecture. European Journal of Marketing, 51(9/10), 1530-1551.

Buechel, E. C., \& Townsend, C. (2018). Buying beauty for the long run: (Mis)predicting liking of product aesthetics. Journal of Consumer Research, 45(2), 275-297.

Caldieraro, F., Kao, L.-J., \& Cunha Jr, M. (2015). Harmful upward line extensions: Can the launch of premium products result in competitive disadvantages? Journal of Marketing, 79(6), 50-70.

Camacho, N., De Jong, M., \& Stremersch, S. (2014). The effect of customer empowerment on adherence to expert advice. International Journal of Research in Marketing, 31(3), 293-308.

Carnevale, M., Luna, D., \& Lerman, D. (2017). Brand linguistics: A theory-driven framework for the study of language in branding. International Journal of Research in Marketing, 34(2), 572-591.

Chang, S.-J., Van Witteloostuijn, A., \& Eden, L. (2010). From the editors: Common method variance in international business research. Journal of International Business Studies, 41(2), 178-184.

Chang, C.-C., Lin, B.-C., \& Chang, S.-S. (2011). The relative advantages of benefit overlap versus category similarity in brand extension evaluation: The moderating role of self-regulatory focus. Marketing Letters, 22(4), 391-404.

Chen, Y., \& Wyer Jr, R. S. (2020). The effects of endorsers' facial expressions on status perceptions and purchase intentions. International Journal of Research in Marketing, 37(2), 371-385.

Chun, H. H., Park, C. W., Eisingerich, A. B., \& MacInnis, D. J. (2015). Strategic benefits of low fit brand extensions: When and why? Journal of Consumer Psychology, 25(4), 577-595.

Çilingirtürk, A. M., \& Koçak, H. (2018). Human Development Index (HDI) rank-order variability. Social Indicators Research, 137(2), 481-504.

Cretu, A. E., \& Brodie, R. J. (2007). The influence of brand image and company reputation where manufacturers market to small firms: A customer value perspective. Industrial Marketing Management, 36(2), 230-240.

Crocker, J. (1984). A Schematic Approach to Changing Consumers' Beliefs. Advances in Consumer Research, 11(1), 472-477.

Cutright, K. M., Bettman, J. R., \& Fitzsimons, G. J. (2013). Putting brands in their place: How a lack of control keeps brands contained. Journal of Marketing Research, 50(3), 365-377.

Davvetas, V., \& Diamantopoulos, A. (2016). How product category shapes preferences toward global and local brands: A schema theory perspective. Journal of International Marketing, 24(4), 61-81.

Davvetas, V., \& Diamantopoulos, A. (2018). "Should Have I Bought the Other One?" Experiencing Regret in Global Versus Local Brand Purchase Decisions. Journal of International Marketing, 26(2), 1-21.

De Mooij, M. (2017). Comparing dimensions of national culture for secondary analysis of consumer behavior data of different countries. International Marketing Review, 34(3), 444-456.

Delassus, V. P., \& Descotes, R. M. (2012). Brand name substitution and brand equity transfer. Journal of Product \& Brand Management, 21(2), 117-125.

Derdenger, T. P. (2018). Examining the impact of celebrity endorsements across consumer segments: An empirical study of Tiger Woods' endorsement effect on golf equipment. Marketing Letters, 29(2), 123-136. 
Diamantopoulos, A., Schlegelmilch, B., \& Palihawadana, D. (2011). The relationship between country-of-origin image and brand image as drivers of purchase intentions. International Marketing Review, 28(5), 508-524.

Dimofte, C. V., Johansson, J. K., \& Ronkainen, I. A. (2008). Cognitive and affective reactions of US consumers to global brands. Journal of International Marketing, 16(4), 113-135.

Dimofte, C. V., Johansson, J. K., \& Bagozzi, R. P. (2010). Global brands in the United States: How consumer ethnicity mediates the global brand effect. Journal of International Marketing, 18(3), 81-106.

DiStefano, C., Zhu, M., \& Mindrila, D. (2009). Understanding and using factor scores: Considerations for the applied researcher. Practical Assessment, Research \& Evaluation, 14(20), 1-11.

Douglas, S. P., \& Craig, C. S. (2006). On improving the conceptual foundations of international marketing research. Journal of International Marketing, 14(1), 1-22.

Dwivedi, A., Merrilees, B., \& Sweeney, A. (2010). Brand extension feedback effects: A holistic framework. Journal of Brand Management, 17(5), 328-342.

Dwivedi, A., McDonald, R. E., \& Johnson, L. W. (2014). The impact of a celebrity endorser's credibility on consumer self-brand connection and brand evaluation. Journal of Brand Management, 21(7-8), $559-578$.

Eggers, F., O’Dwyer, M., Kraus, S., Vallaster, C., \& Güldenberg, S. (2013). The impact of brand authenticity on brand trust and SME growth: A CEO perspective. Journal of World Business, 48(3), $340-348$.

Erdem, T., Swait, J., \& Valenzuela, A. (2006). Brands as signals: A cross-country validation study. Journal of Marketing, 70(1), 34-49.

Erfgen, C., Zenker, S., \& Sattler, H. (2015). The vampire effect: When do celebrity endorsers harm brand recall? International Journal of Research in Marketing, 32(2), 155-163.

Essoussi, L. H., \& Merunka, D. (2007). Consumers' product evaluations in emerging markets: Does country of design, country of manufacture, or brand image matter? International Marketing Review, 24(4), 409-426.

Estes, Z., Gibbert, M., Guest, D., \& Mazursky, D. (2012). A dual-process model of brand extension: Taxonomic feature-based and thematic relation-based similarity independently drive brand extension evaluation. Journal of Consumer Psychology, 22(1), 86-101.

Fatma, M., Khan, I., \& Rahman, Z. (2016). How does corporate association influence consumer brand loyalty? Mediating role of brand identification. Journal of Product \& Brand Management, 25(7), 629-641.

Felix, R., \& Borges, A. (2014). Celebrity endorser attractiveness, visual attention, and implications for ad attitudes and brand evaluations: A replication and extension. Journal of Brand Management, 21(7-8), 579-593.

Ferguson, J. L., \& Mohan, M. (2020). Use of celebrity and non-celebrity persons in B2B advertisements: Effects on attention, recall, and hedonic and utilitarian attitudes. Industrial Marketing Management, 89(August), 594-604.

Fiske, S. T., \& Taylor, S. E. (1991). Social cognition (Vol. 2). Mcgraw-Hill Book Company.

Ford, J. B., Merchant, A., Bartier, A.-L., \& Friedman, M. (2018). The cross-cultural scale development process: The case of brand-evoked nostalgia in Belgium and the United States. Journal of Business Research, 83(February), 19-29.

Frank, P., \& Watchravesringkan, K. T. (2016). Exploring antecedents and consequences of young consumers' perceived global brand equity. Journal of Product \& Brand Management, 25(2), 160-170.

Geldhof, G. J., Preacher, K. J., \& Zyphur, M. J. (2014). Reliability estimation in a multilevel confirmatory factor analysis framework. Psychological Methods, 19(1), 72-91.

Goetz, D. M., Fassnacht, M., \& Rumpf, K. (2014). Extending downward is not always bad: Parent brand evaluations after brand extension to higher and lower price and quality levels. Journal of Brand Management, 21(4), 303-324.

Gray, E. R., \& Balmer, J. M. (1998). Managing corporate image and corporate reputation. Long Range Planning, 31(5), 695-702.

Gupta, S., \& Wright, O. (2019). How Global Brands Can Respond to Local Competitors. Retrieved January 12, 2021, from https://hbr.org/2019/02/how-global-brands-can-respond-to-local-competitors.

Gupta, S., Pansari, A., \& Kumar, V. (2018). Global customer engagement. Journal of International Marketing, 26(1), 4-29.

Gürhan-Canli, Z., Sarial-Abi, G., \& Hayran, C. (2018). Consumers and brands across the globe: Research synthesis and new directions. Journal of International Marketing, 26(1), 96-117. 
Hair, J. F., Black, W. C., Babin, B. J., Anderson, R. E., \& Tatham, R. L. (2018). Multivariate data analysis (Vol. 8). Cengage.

Halkias, G. (2015). Mental representation of brands: A schema-based approach to consumers' organization of market knowledge. Journal of Product \& Brand Management, 24(5), 438-448.

Halkias, G., Davvetas, V., \& Diamantopoulos, A. (2016). The interplay between country stereotypes and perceived brand globalness/localness as drivers of brand preference. Journal of Business Research, 69(9), 3621-3628.

Halkias, G., Micevski, M., Diamantopoulos, A., \& Milchram, C. (2017). Exploring the effectiveness of foreign brand communication: Consumer culture ad imagery and brand schema incongruity. Journal of Business Research, 80(November), 210-217.

Hausman, J. A. (1978). Specification tests in econometrics. Econometrica, 46(6), 1251-1271.

Hayes, A. F. (2017). Introduction to mediation, moderation, and conditional process analysis: A regression-based approach. Guilford Publications.

He, J., \& Wang, C. L. (2017). How global brands incorporating local cultural elements increase consumer purchase likelihood: An empirical study in China. International Marketing Review, 34(4), 463-479.

He, Y., Chen, Q., Tam, L., \& Lee, R. P. (2016). Managing sub-branding affect transfer: The role of consideration set size and brand loyalty. Marketing Letters, 27(1), 103-113.

Heinberg, M., Ozkaya, H. E., \& Taube, M. (2017). The influence of global and local iconic brand positioning on advertising persuasion in an emerging market setting. Journal of International Business Studies, 48(8), 1009-1022.

Heinberg, M., Ozkaya, H. E., \& Taube, M. (2018). Do corporate image and reputation drive brand equity in India and China?-Similarities and differences. Journal of Business Research, 86(May), 259-268.

Henseler, J., Horváth, C., Sarstedt, M., \& Zimmermann, L. (2010). A cross-cultural comparison of brand extension success factors: A meta-study. Journal of Brand Management, 18(1), 5-20.

Hox, J. J., Moerbeek, M., \& Van de Schoot, R. (2018). Multilevel Analysis: Techniques and Applications. Routledge.

Hoyer, W. D., MacInnis, D. J., \& Pieters, R. (2012). Consumer behavior (Vol. 6). Cengage.

Hsieh, M.-H., Pan, S.-L., \& Setiono, R. (2004). Product-, corporate-, and country-image dimensions and purchase behavior: A multicountry analysis. Journal of the Academy of Marketing Science, 32(3), 251-270.

Hsu, L., Fournier, S., \& Srinivasan, S. (2016). Brand architecture strategy and firm value: How leveraging, separating, and distancing the corporate brand affects risk and returns. Journal of the Academy of Marketing Science, 44(2), 261-280.

Hu, J., Liu, X., Wang, S., \& Yang, Z. (2012). The role of brand image congruity in Chinese consumers' brand preference. Journal of Product \& Brand Management, 21(1), 26-34.

Huber, F., Lenzen, M., Meyer, F., \& Weihrauch, A. (2013). Brand extensions in the platform countries of Asia-Effects of fit, order of market entry and involvement. Journal of Brand Management, 20(5), 424-443.

Iglesias, O., Markovic, S., Singh, J. J., \& Sierra, V. (2019). Do customer perceptions of corporate services brand ethicality improve brand equity? Considering the roles of brand heritage, brand image, and recognition benefits. Journal of Business Ethics, 154(2), 441-459.

Ilicic, J., Baxter, S. M., \& Kulczynski, A. (2016). The impact of age on consumer attachment to celebrities and endorsed brand attachment. Journal of Brand Management, 23(3), 273-288.

Iversen, N. M., \& Hem, L. E. (2011). Reciprocal transfer effects for brand extensions of global or local origin: Evidence from Norway. International Marketing Review, 28(4), 365-411.

Jak, S., Oort, F. J., \& Dolan, C. V. (2013). A test for cluster bias: Detecting violations of measurement invariance across clusters in multilevel data. Structural Equation Modeling: A Multidisciplinary Journal, 20(2), 265-282.

Jakubanecs, A., \& Supphellen, M. (2012). Blank endorsement: The added value of unknown corporate brands. Journal of Brand Management, 19(9), 788-800.

Johnson, Z. S., Mao, H., Lefebvre, S., \& Ganesh, J. (2019). Good Guys Can Finish First: How Brand Reputation Affects Extension Evaluations. Journal of Consumer Psychology, 29(4), 565-583.

Keller, K. L. (1993). Conceptualizing, measuring, and managing customer-based brand equity. Journal of Marketing, 57(1), 1-22.

Keller, K. L. (2012). Brand strategy. In V. Shankar \& G. S. Carpenter (Eds.), Handbook of marketing strategy (pp. 289-305). Edward Elgar Publishing. 
Kellogg's (2019). 2019 Annual Report. Retrieved June 3, 2020, from https://investor.kelloggs.com/ Cache/IRCache/75664203-bf77-5639-5384-379afa55e05c.PDF?O=PDF\&T $=\& Y=\& D=\& F I D=$ 75664203-bf77-5639-5384-379afa55e05c\&iid=4133514.

Khojastehpour, M., \& Johns, R. (2015). The role of MNC's subsidiaries in creating multinational corporate brand. Journal of Strategic Marketing, 23(6), 512-525.

Kim, K., \& Park, J. (2019). Cultural influences on brand extension judgments: Opposing effects of thinking style and regulatory focus. International Journal of Research in Marketing, 36(1), 137-150.

Kim, J., Spence, M. T., \& Marshall, R. (2018). The color of choice: The influence of presenting product information in color on the compromise effect. Journal of Retailing, 94(2), 167-185.

Kirca, A. H., Randhawa, P., Talay, M. B., \& Akdeniz, M. B. (2020). The interactive effects of product and brand portfolio strategies on brand performance: Longitudinal evidence from the US automotive industry. International Journal of Research in Marketing, 37(2), 421-439.

Kline, R. B. (2015). Principles and practice of structural equation modeling. The Guilford Press.

Knoll, J., \& Matthes, J. (2017). The effectiveness of celebrity endorsements: A meta-analysis. Journal of the Academy of Marketing Science, 45(1), 55-75.

Kwon, M., Saluja, G., \& Adaval, R. (2015). Who said what: The effects of cultural mindsets on perceptions of endorser-message relatedness. Journal of Consumer Psychology, 25(3), 389-403.

Laforet, S., \& Chen, J. (2012). Chinese and British consumers' evaluation of Chinese and international brands and factors affecting their choice. Journal of World Business, 47(1), 54-63.

Lane, V. R., \& Fastoso, F. (2016). The impact of repeated ad exposure on spillover from low fit extensions to a global brand. International Marketing Review, 33(2), 298-318.

Lindell, M. K., \& Whitney, D. J. (2001). Accounting for common method variance in cross-sectional research designs. Journal of Applied Psychology, 86(1), 114-121.

Liu, Y., Foscht, T., Eisingerich, A. B., \& Tsai, H.-T. (2018). Strategic management of product and brand extensions: Extending corporate brands in B2B vs. B2C markets. Industrial Marketing Management, 71, 147-159.

Mandler, T. (2019). Beyond reach: An extended model of global brand effects. International Marketing Review, 36(5), 647-674.

Maydeu-Olivares, A. (2017). Maximum likelihood estimation of structural equation models for continuous data: Standard errors and goodness of fit. Structural Equation Modeling: A Multidisciplinary Journal, 24(3), 383-394.

Meyers-Levy, J., \& Tybout, A. M. (1989). Schema congruity as a basis for product evaluation. Journal of Consumer Research, 16(1), 39-54.

Milberg, S. J., Sinn, F., \& Goodstein, R. C. (2010). Consumer reactions to brand extensions in a competitive context: Does fit still matter? Journal of Consumer Research, 37(3), 543-553.

Miniard, P. W., Jayanti, R. K., Alvarez, C. M., \& Dickson, P. R. (2018). What brand extensions need to fully benefit from their parental heritage. Journal of the Academy of Marketing Science, 46(5), 948-963.

Monga, A. B., \& Gürhan-Canli, Z. (2012). The influence of mating mind-sets on brand extension evaluation. Journal of Marketing Research, 49(4), 581-593.

Muroyiwa, O., Abratt, R., \& Mingione, M. (2017). The effect of vertical brand extensions on consumerbrand relationships in South Africa. Journal of Business Management, 48(1), 1-10.

Nagase, M., \& Kano, Y. (2017). Identifiability of nonrecursive structural equation models. Statistics \& Probability Letters, 122(3), 109-117.

Nicolau, J. L., \& Santa-María, M. J. (2013). Celebrity endorsers' performance on the "ground" and on the "floor." Marketing Letters, 24(2), 143-149.

Özsomer, A. (2012). The interplay between global and local brands: A closer look at perceived brand globalness and local iconness. Journal of International Marketing, 20(2), 72-95.

Park, C. W., Jaworski, B. J., \& MacInnis, D. J. (1986). Strategic brand concept-image management. Journal of Marketing, 50(4), 135-145.

Parker, J. R., Lehmann, D. R., Keller, K. L., \& Schleicher, M. G. (2018). Building a multi-category brand: When should distant brand extensions be introduced? Journal of the Academy of Marketing Science, 46(2), 300-316.

Pedeliento, G., Andreini, D., Bergamaschi, M., \& Salo, J. (2016). Brand and product attachment in an industrial context: The effects on brand loyalty. Industrial Marketing Management, 53(February), 194-206. 
Pedersen, M. J., \& Nielsen, C. V. (2016). Improving survey response rates in online panels: Effects of low-cost incentives and cost-free text appeal interventions. Social Science Computer Review, 34(2), 229-243.

Plumeyer, A., Kottemann, P., Böger, D., \& Decker, R. (2019). Measuring brand image: A systematic review, practical guidance, and future research directions. Review of Managerial Science, 13(2), 227-265.

Puligadda, S., Ross Jr, W. T., \& Grewal, R. (2012). Individual differences in brand schematicity. Journal of Marketing Research, 49(1), 115-130.

Puligadda, S., Cronley, M., \& Kardes, F. (2013). Effects of advertising cues on brand extension evaluation: A global versus focused processing style account. Journal of Brand Management, 20(6), 473-487.

Putrevu, S., \& Lord, K. R. (1994). Comparative and noncomparative advertising: Attitudinal effects under cognitive and affective involvement conditions. Journal of Advertising, 23(2), 77-91.

Ramanathan, J., \& Velayudhan, S. K. (2015). Consumer evaluation of brand extensions: Comparing goods to goods brand extensions with goods to services. Journal of Brand Management, 22(9), $778-801$.

Riefler, P. (2012). Why consumers do (not) like global brands: The role of globalization attitude, GCO and global brand origin. International Journal of Research in Marketing, 29(1), 25-34.

Rodrigo, P., Khan, H., \& Ekinci, Y. (2019). The determinants of foreign product preference amongst elite consumers in an emerging market. Journal of Retailing and Consumer Services, 46(January), 139-148.

Roy, S., Guha, A., \& Biswas, A. (2015). Celebrity endorsements and women consumers in India: How generation-cohort affiliation and celebrity-product congruency moderate the benefits of chronological age congruency. Marketing Letters, 26(3), 363-376.

Roy, S., Guha, A., Biswas, A., \& Grewal, D. (2019). Celebrity endorsements in emerging markets: Align endorsers with brands or with consumers? Journal of International Business Studies, 50(3), 295-317.

Ryu, E. (2015). The role of centering for interaction of level 1 variables in multilevel structural equation models. Structural Equation Modeling: A Multidisciplinary Journal, 22(4), 617-630.

Salinas, E. M., \& Pérez, J. M. P. (2009). Modeling the brand extensions' influence on brand image. Journal of Business Research, 62(1), 50-60.

Samiee, S. (2019). Reflections on global brands, global consumer culture and globalization. International Marketing Review, 36(4), 536-544.

Schwartz, S. H. (1994). Beyond individualism/collectivism: New cultural dimensions of values. Sage.

Shams, R., Alpert, F., \& Brown, M. (2015). Consumer perceived brand innovativeness. European Journal of Marketing, 49(9/10), 1599-1615.

Shaw, J. B. (1990). A cognitive categorization model for the study of intercultural management. Academy of Management Review, 15(4), 626-645.

Sheth, J. N. (2011). Impact of emerging markets on marketing: Rethinking existing perspectives and practices. Journal of Marketing, 75(4), 166-182.

Sichtmann, C., \& Diamantopoulos, A. (2013). The impact of perceived brand globalness, brand origin image, and brand origin-extension fit on brand extension success. Journal of the Academy of Marketing Science, 41(5), 567-585.

Souiden, N., Kassim, N. M., \& Hong, H. J. (2006). The effect of corporate branding dimensions on consumers' product evaluation: A cross-cultural analysis. European Journal of Marketing, 40(7/8), 825-845.

Souiden, N., Amara, N., \& Chaouali, W. (2020). Optimal image mix cues and their impacts on consumers' purchase intention. Journal of Retailing and Consumer Services, 54(May), 1-12.

Spiggle, S., Nguyen, H. T., \& Caravella, M. (2012). More than fit: Brand extension authenticity. Journal of Marketing Research, 49(6), 967-983.

Spiller, S. A., Fitzsimons, G. J., Lynch Jr, J. G., \& McClelland, G. H. (2013). Spotlights, floodlights, and the magic number zero: Simple effects tests in moderated regression. Journal of Marketing Research, 50(2), 277-288.

Steenkamp, J.-B. (2019a). Global versus local consumer culture: Theory, measurement, and future research directions. Journal of International Marketing, 27(1), 1-19.

Steenkamp, J.-B. (2019b). Reflections on defining global brands, fragmentation and segmentation, and the emergence of richer brandscapes. International Marketing Review, 36(4), 553-555. 
Steenkamp, J.-B. E., \& Baumgartner, H. (1998). Assessing measurement invariance in cross-national consumer research. Journal of Consumer Research, 25(1), 78-90.

Steenkamp, J.-B. E., \& Geyskens, I. (2006). How country characteristics affect the perceived value of web sites. Journal of Marketing, 70(3), 136-150.

Steenkamp, J.-B. E., Batra, R., \& Alden, D. L. (2003). How perceived brand globalness creates brand value. Journal of International Business Studies, 34(1), 53-65.

Stock, J. H., \& Watson, M. W. (2019). Introduction to econometrics (Vol. 4). Pearson.

Stokburger-Sauer, N., Ratneshwar, S., \& Sen, S. (2012). Drivers of consumer-brand identification. International Journal of Research in Marketing, 29(4), 406-418.

Strizhakova, Y., \& Coulter, R. A. (2015). Drivers of local relative to global brand purchases: A contingency approach. Journal of International Marketing, 23(1), 1-22.

Strizhakova, Y., Coulter, R. A., \& Price, L. L. (2011). Branding in a global marketplace: The mediating effects of quality and self-identity brand signals. International Journal of Research in Marketing, 28(4), 342-351.

Suh, J. C., \& Youjae, Y. (2006). When brand attitudes affect the customer satisfaction-loyalty relation: The moderating role of product involvement. Journal of Consumer Psychology, 16(2), 145-155.

Sujan, M., \& Bettman, J. R. (1989). The effects of brand positioning strategies on consumers' brand and category perceptions: Some insights from schema research. Journal of Marketing Research, 26(4), 454-467.

Swoboda, B., \& Batton, N. (2019). National cultural value models and reputation of MNCs. Cross Cultural \& Strategic Management, 26(2), 166-198.

Swoboda, B., \& Sinning, C. (2020). How country development and national culture affect the paths of perceived brand globalness to consumer behavior across nations. Journal of Business Research, $118(9), 58-73$.

Swoboda, B., Puchert, C., \& Morschett, D. (2016). Explaining the differing effects of corporate reputation across nations: A multilevel analysis. Journal of the Academy of Marketing Science, 44(4), 454-473.

Thompson, F. M., Newman, A., \& Liu, M. (2014). The moderating effect of individual level collectivist values on brand loyalty. Journal of Business Research, 67(11), 2437-2446.

United Nations Development Programme (2018). Human Development Index. Retrieved January 10, 2020, from http://hdr.undp.org/sites/default/files/hdr2019.pdf.

Vaid, S. S., \& Ahearne, M. (2018). When does CEO endorsement of sales \& marketing leaders help firms? The role of heavy marketing emphasis. Industrial Marketing Management, 69(February), 185-197.

Van der Lans, R., van Everdingen, Y., \& Melnyk, V. (2016). What to stress, to whom and where? A cross-country investigation of the effects of perceived brand benefits on buying intentions. International Journal of Research in Marketing, 33(4), 924-943.

Visentin, M., Pizzi, G., \& Pichierri, M. (2019). Fake News, Real Problems for Brands: The Impact of Content Truthfulness and Source Credibility on consumers' Behavioral Intentions toward the Advertised Brands. Journal of Interactive Marketing, 45(February), 99-112.

Voss, K. E., \& Mohan, M. (2016). Corporate brand effects in brand alliances. Journal of Business Research, 69(10), 4177-4184.

Walsh, G., Beatty, S. E., \& Shiu, E. M. (2009). The customer-based corporate reputation scale: Replication and short form. Journal of Business Research, 62(10), 924-930.

Wang, X., \& Yang, Z. (2008). Does country-of-origin matter in the relationship between brand personality and purchase intention in emerging economies? International Marketing Review, 25(4), 458-474.

Wang, H., Wei, Y., \& Yu, C. (2008). Global brand equity model: Combining customer-based with product-market outcome approaches. Journal of Product \& Brand Management, 17(5), 305-316.

Wang, C. L., Li, D., Barnes, B. R., \& Ahn, J. (2012). Country image, product image and consumer purchase intention: Evidence from an emerging economy. International Business Review, 21(6), 1041-1051.

Wang, C. L., He, J., \& Barnes, B. R. (2017). Brand management and consumer experience in emerging markets: Directions for future research. International Marketing Review, 34(4), 458-462.

Watkins, L. (2010). The cross-cultural appropriateness of survey-based value (s) research: A review of methodological issues and suggestion of alternative methodology. International Marketing Review, 27(6), 694-716. 
Wilkie, D. C., Johnson, L. W., \& White, L. (2015). The line extension dilemma: Greater difference or similarity to existing products? Journal of Brand Management, 22(6), 534-550.

Williams, L. J., Hartman, N., \& Cavazotte, F. (2010). Method variance and marker variables: A review and comprehensive CFA marker technique. Organizational Research Methods, 13(3), 477-514.

Xie, Y., Batra, R., \& Peng, S. (2015). An extended model of preference formation between global and local brands: The roles of identity expressiveness, trust, and affect. Journal of International Marketing, 23(1), 50-71.

Yang, Z., Floyd, K., \& Tanner Jr, J. F. (2019). Effects of antismoking messages from media on adolescent smoking: The roles of family, school, and culture. Journal of Business Research, 103, 222-231.

Zabkar, V., Arslanagic-Kalajdzic, M., Diamantopoulos, A., \& Florack, A. (2017). Brothers in blood, yet strangers to global brand purchase: A four-country study of the role of consumer personality. Journal of Business Research, 80, 228-235.

Publisher's Note Springer Nature remains neutral with regard to jurisdictional claims in published maps and institutional affiliations. 